\title{
El homenaje marino. Monumento a Antonio López en Comillas
}

\author{
Marine tribute \\ Monument to Antonio Lopez in Comillas
}

ANTONIO SAMA GARCÍA

Real Fábrica de Tapices. Madrid

girasol130@realfabricadetapices.com

Recibido: $25 / 07 / 2013$

Aceptado: 19/09/2013

\begin{abstract}
Resumen
El caso de Antonio López y López (Comillas 1817-Barcelona 1883) es uno de los ejemplos más paradigmáticos de la leyenda del indiano. Enriquecido en Cuba, volvió a la Península para establecerse en Barcelona y construir uno de los conglomerados económicos más importantes de la Restauración. Distinguido por Alfonso XII con el título de marqués en 1878, comenzó a partir de entonces a dignificar su villa natal mediante un espléndido mecenazgo. A Comillas llegaron, entonces, algunos de los mejores artistas catalanes del último cuarto de siglo. Continuando con esta línea de patrocinio, el monumento a Antonio López (1883-1892) fue encargado a Lluís Domènech i Montaner y constituye uno de los hitos del arte de la Renaixença en Comillas.
\end{abstract}

Palabras clave: Lluís Domènech i Montaner, Cristòfol Cascante i Colom, Comillas, marquesado de Comillas, escultura monumental, Renaixença 


\begin{abstract}
The case of Antonio López y López (Comillas 1817-Barcelona 1883) is one of the most paradigmatic examples of the indiano legend. Having become rich in Cuba, he returned to the Iberian Peninsula to settle in Barcelona and build one of the foremost economic conglomerates of the Restoration. Honored by Alfonso XII with the title of marquis in 1878, he then started to dignify his native town through a splendid patronage. At the time, Comillas witnessed the arrival of some of the best Catalan artirts of the last fourth of the century. In line with this patronage, the monument to Antonio López (1883-1892) was commissioned from Lluís Domènech i Montaner and represents one of the milestones of the Renaixença art in Comillas.
\end{abstract}

Key words: Lluís Domènech i Montaner, Cristòfol Cascante i Colom, Comillas, Marquisate of Comillas, monumental sculpture, Renaixença

Sumario: 1. Introducción. 2. Cuetiones de cronología y autoría. 3. Simbología del memorial a Antonio López. 3. El monumento tras la Guerra Civil. 4. Bibliografía.

\title{
1. Introducción.
}

En un promontorio frente al mar, encaramado a la inmensidad oceánica, todavía domina la costa comillana el monumento que los naturales del lugar quisieron levantar a la memoria de Antonio López y López, primer marqués de Comillas. Desde ese elevado enclave, la estatua del que fue fundador de la Compañía Trasatlántica parece otear el horizonte en busca de los vapores de acero que fueron el origen de su fama y fortuna ${ }^{1}$.

\footnotetext{
${ }^{1}$ De humilde origen, el cántabro Antonio López (Comillas 1817 - Barcelona 1883) llegará a amasar una de las primeras fortunas de la España de la Restauración y a convertirse en uno de los personajes más influyentes de su época. Prototipo del indiano emprendedor y sagaz, López cimentó las bases de su poderío económico en la isla de Cuba, donde se afinca hacia 1830. Allí comenzó a trabajar en el pequeño comercio y, tras establecerse por su cuenta, inició su enriquecimiento personal con la compra-venta de esclavos, el transporte marítimo y la especulación inmobiliaria. No está demostrado que se dedicara a la trata, es decir, al tráfico de esclavos (actividad ya ilícita por entonces), pero esta "leyenda negra" le perseguirá durante toda su vida prácticamente desde su llegada a Barcelona. En esta ciudad se radica ya definitivamente a partir 1856 para empezar a construir un imperio naviero íntimamente vinculado a las contratas estatales del servicio de correo ultramarino. La empresa emblemática del conglomerado financiero y empresarial de lo que se ha venido a llamar el "grupo Comillas" será la naviera A. López
} 
El monumento comillano constituye uno de los homenajes más perdurables que se levantaron en honor del ilustre prócer tras su repentina muerte del 16 de enero de 1883. El más inmediato y urgente es el que quedó plasmado en la prensa contemporánea en forma de innumerables necrologías y panegíri$\cos ^{2}$, pero en Barcelona también se erigió un memorial construido según los planos de Oriol Mestres y en Santander hubo intención de hacer otro.

Es lógico que los paisanos de Antonio López quisieran honrar la memoria de quien había enriquecido la villa con gestos de espléndido mecenazgo: la construcción de la Capilla-panteón (1878-1881) y el Palacio de Sobrellano (1881-1887), el proyecto de crear un Seminario para pobres bajo la dirección de los padres jesuitas, etc., etc. Pero quizás por lo que los comillanos le estaban más agradecidos al marqués era por haber atraído a la pequeña población cántabra a Alfonso XII y su corte durante los estíos de 1881 y 1882. Durante aquellas Jornadas Regias, Comillas se transformó como en un cuento de hadas y pasó de villa marinera a moderno enclave del veraneo aristocrático ${ }^{3}$. Como veremos más adelante, algo de los fastos de aquellas Jornadas parece haberse petrificado en lo que los comillanos conocen desde hace más de un siglo como "la estatua".

y Cia (dotada con más de 13 vapores), a partir de 1881 transformada en la Compañía Trasatlántica. Pero el indiano comillano fue, además, el promotor de otras importantes iniciativas empresariales como el Banco Hispano-Colonial, el Crédito Mercantil, el Banco de Castilla o la Compañía General de Tabacos de Filipinas, y socio de otras como la Compañia de Caminos de Hierro del Norte de España. Al final de su vida, pues, Antonio López acumuló una ingente cantidad de dinero, pero también muchas dignidades: Marqués de Comillas (en 1878, como recompensa a su decisiva contribución para sofocar la insurrección cubana de 1876), Grande de España, senador del Reino vitalicio, Gran Cruz de Carlos III e Isabel la Católica...

${ }^{2}$ Para la selección de necrológicas recopiladas en Barcelona, véase Homenaje que la ciudad de Barcelona tributó a la memoria del Excmo. Sr. D. Antonio López y López, Marqués de Comillas, Barcelona, Imprenta Peninsular, 1883. Para las de Madrid, Homenaje nacional a la memoria del Excmo. Señor D. Antonio López y López, primer Marqués de Comillas, fallecido en Barcelona el día 16 de enero de 1883 (1883b) Madrid, Sucesores de Rivadeneyra. La única biografía sobre el primer marqués apareció en Santander el mismo año de su fallecimiento: Del Río, José Antonio (1883): El Exmo. Sr. D. Antonio López y López, primer Marqués de Comillas, Santander, Imprenta de Río hermanos. ${ }^{3} \mathrm{Vid}$. "El sueño de unas Jornadas de verano: arte y metamorfosis en la celebración de los veraneos regios de Comillas (1881 y 1882)", en Actas de las I Jornadas Internacionales de Investigación Arte y Ciudad, Madrid, Facultad de Ciencias de la Información, UCM (24-25 de noviembre de 2011), 2012, pp. 75-91. http://www.arteyciudad.com/revista/index.php/actas/article/view/34 
Casado con una catalana y radicados sus negocios en la Ciudad Condal, Antonio López había llevado a cabo sus proyectos de "legitimación social" (la construcción del palacio marquesal y del panteón familiar) contando con algunos de los mejores artistas catalanes del momento. Sus sucesores continuaron esta tendencia, de manera que la villa natal del fundador de la Trasatlántica se convirtió en una especie de muestrario del arte de la Renaixença, el movimiento socio-cultural de afirmación nacional que domina el último cuarto del s. XIX en Cataluña. La estatua de homenaje levantada frente a la playa se enmarca dentro de ese programa de monumentalización que la familia López y otros allegados llevan a cabo tras la muerte del primer marqués y constituye, por lo tanto, uno de los hitos de la Renaixença en Comillas.

\section{Cuestiones de cronología y autoría.}

Como era de esperar, los comillanos se apresuraron a poner en marcha la iniciativa para inmortalizar la memoria del marqués, al mismo tiempo que en Barcelona y Santander se hacía lo mismo.

Así, el Ayuntamiento de Comillas acordó en la sesión del 23 de enero de 1883 promover una suscripción para levantar una estatua y nombrar una Comisión para recabar los fondos y llevar a cabo el proyecto:

El pueblo de Comillas está verdaderamente de luto con la reciente muerte de su preclaro hijo; el ilustre prócer D. Antonio Lopez y Lopez, que había llegado á la cumbre de 'los honores y de la fortuna, sembrando beneficios por todos los pasos de su vida.

Las bendiciones con que hoy le recuerdan, no sólo los hijos de este pueblo sino los de Santander, Barcelona, Cádiz y tantos otros á donde tambien alcanzaron los incalculables efectos de su corazon inagotable de bondades, son la demostracion más elocuente del acendrado cariño que ha logrado inspirar el egregio varon que parecia destinado por la Providencia para remediar desgracias, aliviar dolores y hacer el bien en todas las sublimes manifestaciones de la caridad cristiana.

Por esta razon, el Ayuntamiento de Comillas, interpretando fielmente los deseos de todo el vecindario, ha tomado, entre otros acuerdos, el de promover una suscricion popular para levantar la estatua del ilustre finado, en testimonio de gratitud de un pueblo que sabe apreciar los beneficios que se le dispensan.

Y á fin de dar la debida amplitud al pensamiento, ha nombrado una Comision 
que se encargue de recaudar los fondos y de facilitar todo lo que sea necesario para la realizacion de esta idea.

Los que suscriben que son los que componen la Comision, al aceptar este honroso encargo se dirigen á todos sus convecinos con la fundadísima esperanza de que muy pronto será un hecho lo que hoy es la aspiracion unánime de la villa. No tratan de hacer exhortaciones de ninguna clase, porque los pensamientos populares no necesitan más empuje que el del levantado sentimiento que los inspira. Los pueblos se honran á sí mismos, al honrar la memoria de sus hijos ilustres.

Esta estatua no sólo será el cumplimiento de un deber de gratitud del pueblo al bienhechor, sino tambien una poderosa enseñanza para los que deben ser bienhechores de los pueblos.

Comillas, Enero 23 de 1883.-EI Presidente, Evaristo Moro y Diaz.- Vicepresidente, Francisco Linares.- Vocales, Carlos Fernández de Castro.-Antonio Sanchez de Movellan.- Victoriano Perez de la Riva.-Juan de Blanco y Álvarez.Vicente Carranceja y Balbás.-Juan Francisco de San Juan.-Máximo Diaz de Quijano-Secretario, Abel Alonso de la Bárcena4.

La voluntad de los comillanos para construir un monumento en homenaje de Antonio López quedó muy pronto, pues, claramente demostrada. Pero a partir de este hecho positivamente documentado, se extiende una densa bruma de dudas acerca de aspectos tan fundamentales como cuándo se encargó el proyecto, a quién, en qué fecha fue realizado... La penuria documental en lo que concierne a esta obra (siguiendo la tónica general de los monumentos comillanos) ha hecho que la mayor parte de lo que se ha venido diciendo hasta la fecha no haya ido mucho más allá de la pura conjetura.

En efecto, todos los autores coinciden en afirmar que el monumento fue proyectado originalmente por Cristòfol Cascante y que después de su muerte, las obras de su construcción fueron llevadas a cabo por Lluís Domènech i Montaner, quien incorporaría algunas reformas sobre el proyecto primigenio. La primera vez que se habla de la autoría de Cascante es en el artículo dedicado por Juan Bassegoda Nonell al arquitecto en el diario La Prensa ${ }^{5}$. El argu-

${ }^{4}$ El acta fue publicada en e1 El Cántabro el 1 de febrero de 1883 y posteriormente también sería reproducida en Homenaje nacional a la memoria del Excmo. Señor D. Antonio López y López, primer Marqués de Comillas, fallecido en Barcelona el día 16 de enero de 1883 Madrid, Sucesores de Rivadeneyra.

${ }^{5}$ Bassegoda i Nonell, Juan (1971): “Arquitectos catalanes del siglo XIX: Cristòfol Cascante Colom", La Prensa, 26 de junio de 1971. 
mento para tal atribución es un dibujo del monumento que se conserva, entre otros papeles del malogrado arquitecto, en la Real Cátedra Gaudí de Barcelona.

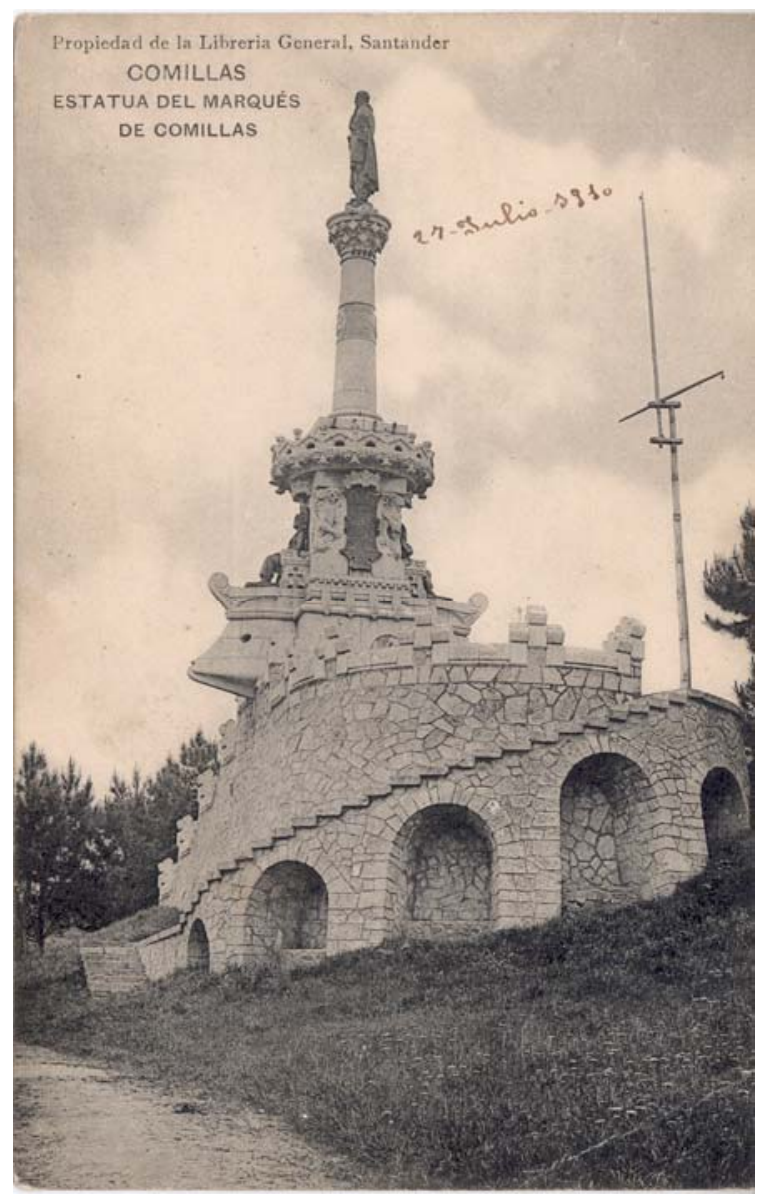

\section{Fig. 1.}

Monumento a Antonio López en Comillas. Postal de 1910.

En este dibujo se puede ver un diseño muy similar al de la obra que finalmente se construyó en Comillas. El basamento tiene forma de doble proa sobre la que se asientan las figuras alegóricas de Filipinas (a la derecha del dibujo) y las Antillas (a la izquierda). Sobre él aparece la figura de un ancla inscrito en un círculo y la inscripción "Construido en 1885". La base de la columna central es un gran prisma con el escudo del marqués sostenido por leones rampantes esculpidos en los chaflanes de los ángulos. Este prisma está cubierto por una especie de dosel circular con un borde esculturado a la manera de 
festón (quizás queriendo sugerir la idea de una corona marquesal) en el que aparece una inscripción corrida con la dedicatoria. En el dibujo se pueden leer las palabras "LOPEZ: LA: CIUDAD:". Del centro de esta corona surge una columna con acusada forma troncocónica y capitel de evocaciones corintias, sobre la que se apoya la estatua de Antonio López. El fuste de la columna presenta unas acanaladuras que parecen aludir a las jarcias de una nave, y la figura del marqués, vestida con gabán, extiende el brazo al horizonte, se supone que señalando al mar.

Casi todos los autores, sin embargo, obvian dos aspectos importantes: en primer lugar, que el encabezado del dibujo dice "Proyecto de monumento a D. Antonio López en Santander" y, en segundo lugar, que el dibujo no lleva firma. Es evidente, por lo tanto, que el proyecto fue pensado para ser emplazado en la ciudad de Santander, tal y como confirma la ambientación paisajística del mismo, en la que Luis Sazatornil reconoce la bahía de la capital cántabra.

En cuanto a la atribución a Cascante, hay dos factores que introducen serias dudas al respecto: en primer lugar, el hecho de no figurar su firma en el proyecto; en segundo, y más importante, la existencia entre los papeles del fondo donado al Arxiu Històric del Col-legi d'Arquitectes de Catalunya, Demarcació de Barcelona por los descendientes de Domènech i Montaner, de unos bocetos que guardan gran parecido con el proyecto de la Real Cátedra Gaudít. No es fácil explicar esta estrecha similitud (que se manifiesta incluso en la misma inscripción) si se defiende que los bocetos y el proyecto pertenecen a autores distintos. En realidad, parece que la génesis del proyecto de Comillas está íntimamente relacionada con la de otro monumento a la memoria de Antonio López que se pensó levantar en Santander. En efecto, en la sesión del Ayuntamiento de Santander correspondiente al 1 de febrero de 1883, se leyó una proposición destinada á honrar la memoria del preclaro montañés D. Antonio Lopez,

${ }^{6}$ COAC, Fondo Domènech i Montaner, carpeta C 1663/21 "Monumento a Antonio López". Dentro de ésta se encuentran dos hojas con esbozos a tinta y lápiz relacionados con el monumento. Uno de ellos presenta por una cara el estudio de uno de los leones rampantes y por la otra el de las figuras alegóricas de las Antillas y Filipinas. La otra hoja presenta un estudio general de composición del monumento que presenta ya las mismas líneas generales del dibujo de la Cátedra Gaudí: columna troncocónica con jarcias, capitel como corintio, dosel circular, etc. Las "Indias" aparecen también en la misma postura. Hay, demás, un detalle del anillo o festón anular en el que se lee la inscripción: "EZ.LA.CIUDA". 
por la que se acordaba abrir una suscripción popular en Santander, Cuba y Barcelona para erigir una estatua en su homenaje en la plazuela de la Libertad7. El acuerdo, por el que el Ayuntamiento se comprometía a aportar 5.000 duros, se tomó justo antes de saberse que el finado había dejado en su testamento un legado de 12.000 duros para la ciudad ${ }^{8}$. Todo parecía indicar, pues, que la iniciativa municipal iba a tener un feliz desenlace, pero por razones que no sabemos, todavía en 1888 el proyecto de levantar el monumento al magnate comillano estaba paralizado 9 . Finalmente, la corporación santanderina consigna en un acta del 21 de abril de 1890 que se desiste de erigir el monumento ${ }^{10}$. Según Benito Madariaga, con el legado de Antonio López se pensó también construir un monumento a Cantabria en 1893 (después de la catástrofe del Cabo Machichaco), pero el proyecto también naufragó, al parecer por la reclamación de tres arquitectos ${ }^{11}$. Definitivamente, el legado acabaría sirviendo para financiar la construcción del edificio para la Caja de Ahorros y Monte de Piedad de Santander, encargado al propio Lluís Domènech.

Diversas noticias, empero, indican que el proyecto de monumento en Santander había comenzado a andar antes de verse paralizado. Siguiendo el orden cronológico, la primera de ellas dice que se ha oido ponderar un plano que se ha recibido de París para el monumento que va a erigirse (en Santander, se supone) para Antonio López ${ }^{12}$. Esto parece indicar que la primera idea para el

\footnotetext{
${ }^{7}$ Boletín de Comercio de Santander, 2 de febrero de 1883.

${ }^{8}$ El marqués de Comillas ha dejado á Santander una manda de 12,000 duros. Précisamente recibió el alcalde la carta que daba de ella cuenta, cuando se acababa de acordar en sesión erigir á don Antonio López una estatua en el centro de la plaza de la Libertad, para lo que se abrirá una suscrición popular en Santander, Barcelona y Cuba, sin perjuicio de 5,000 duros que el municipio de Santander consigna. Otra estatua se elevará en Comillas, también por suscrición popular, La Vanguardia, 7 de febrero de 1883, p. 4.

${ }^{9}$ En El Correo de Cantabria del 4 de abril de 1888 se habla del legado de Antonio López, por el que se dan al Ayuntamiento de Santander 60.000 pts para una obra pública cualquiera. A partir de su muerte se pensó en levantarle un monumento, dice, pero constata que se ha paralizado la cosa. Se pregunta el autor si no es hora de replantearse la cuestión, ya que hay una suscripción hecha y el segundo marqués está dispuesto a aportar más fondos.

${ }^{10}$ Así se refleja en el artículo titulado "La Estatua al Excmo. Sr. Marqués de Comillas", publicado en el Boletín de Comercio del 22 de abril de 1890, en el que el autor manifiesta su sentimiento por esta decisión.

${ }_{11}$ Madariaga (1986: 88). De la correspondiente comisión formaron parte Pereda, Marcelino Menéndez Pelayo, Escalante, Ángel de los Ríos y otros.

${ }^{12}$ La Verdad, Santander, 15 de abril de 1883.
} 
monumento se había pedido a algún arquitecto francés. Algunos meses después, sin embargo, la prensa de Barcelona lanza la noticia de que el proyecto se había encargado a Domènech:

Han sigut encarregats los planos del sumptuós monumento que ha de aixecarse en Santander en memoria del Excmo. Sr. Antoni Lopez y Lopez, al distinguit é inteligente arquitecte D. Lluís Domènech i Montaner ${ }^{13}$.
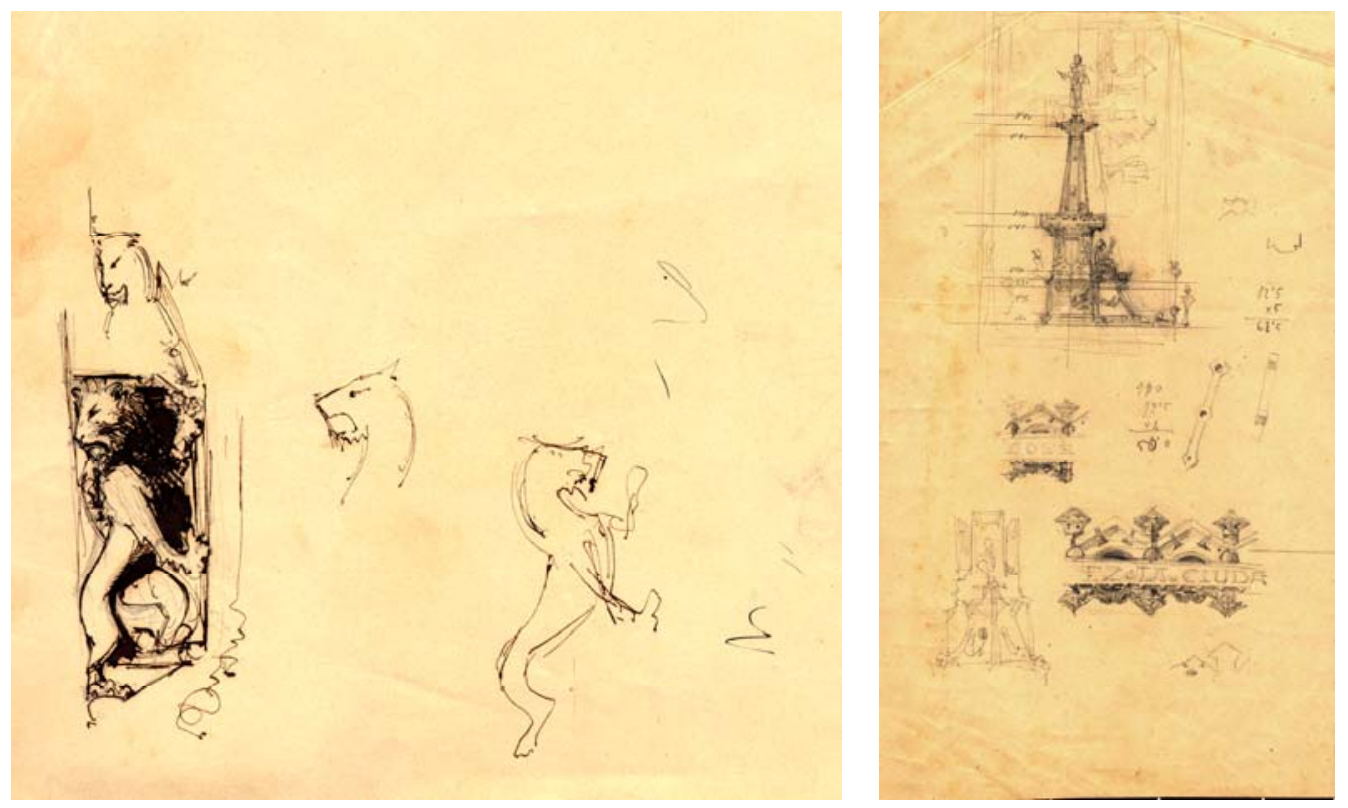

Figs. 2 y 3. Bocetos de Domènech i Montaner para el Monumento a Antonio López en Comillas, AHCOAC.

Poco después, una noticia aparecida en La Vanguardia decía así:

Los cuatro bajo-relieves que deben formar parte de la ornamentación del monumento que en el pueblo de Comillas se está levantando al primer marqués de este nombre Excmo. señor don Antonio López y López, han sido encargados á

${ }^{13}$ La Renaixensa, 27 de octubre 1883, edición tarde. Una noticia muy semejante apareció al día siguiente en otro diario de Barcelona: Han sido encargados los planos del suntuoso monumento que ha de levantarse en Santander a la memoria del marqués de Comillas, a nuestro paisano don Luis Domenech, La Crónica de Cataluña, 28 de octubre de 1883, domingo. 
nuestros paisanos los reputados escultores señores Nobas, Roig, Pagés y Serratosa y Puiggener ${ }^{14}$.

Pero sin duda, se trataba de una confusión con el memorial que se estaba levantando por entonces en Barcelona.

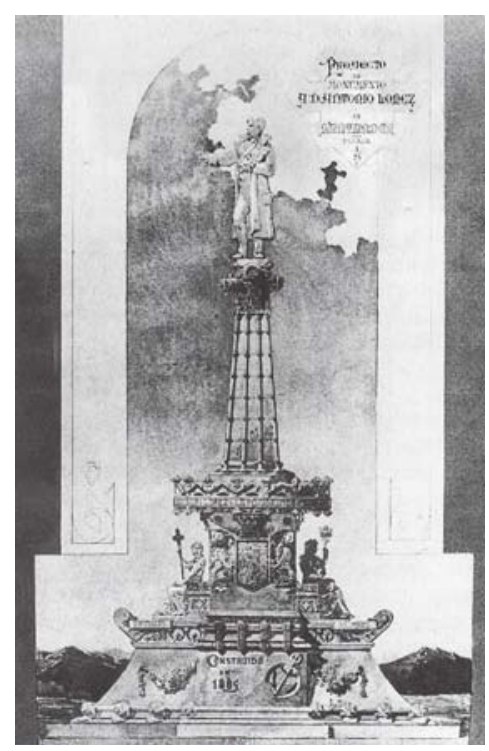

Fig. 4. Proyecto de un monumento a Antonio López en Santander. Cristóbal Cascante. Cátedra Gaudí

numento se emplazará en un punto elevado con vistas al mar Cantábrico ${ }^{16}$.

La última noticia que hemos localizado en relación con el proyecto de Santander menciona ya a Agapito Vallmitjana y afirma que:

El reputado escultor don Agapito Vallmitjana, está modelando una estatua de don Antonio López y López, que ha de coronar el monumento que se erige en Santander á la memoria de dicho naviero. Se habla con grande elogio de la obra del señor Vallmitjana ${ }^{15}$.

A partir de aquí, las siguientes noticias que aparecen en la prensa relacionadas con la construcción del monumento se refieren ya a Comillas. Las primeras de ellas anuncian la salida para la villa de los López de Domènech i Montaner:

El arquitecto don Luis Domenech i Montaner, autor del proyecto que en Comillas se va á levantar á don Antonio López y López, ha salido para aquella población á fin de dar comienzo á las obras. El Mo-

La noticia de los periódicos catalanes es confirmada por el Boletín de Comercio de Santander, que menciona al arquitecto entre los bañistas tardíos de

\footnotetext{
${ }^{14}$ La Vanguardia, 12 de diciembre de 1883, p. 3.

${ }^{15}$ La Vanguardia, 20 de septiembre de 1885, p. 5. Una noticia muy similar fue publicada también por La Renaixensa el mismo día, y dos días después también por el madrileño El Globo.

${ }^{16}$ Diario de Barcelona, 6 de agosto de 1889, edición de la tarde, p. 9754. El mismo día, La Vanguardia: sacó un "suelto" muy parecido: Ha salido para Comillas el celebrado arquitecto don Luis Domenech y Montaner, autor del proyecto de monumento que en aquella poblaci6n se va a levantar a la memoria del difunto naviero don Antonio Lopez y Lopez. El monumento se levantará en un punto elevado, con vistas al Cantábrico, emprendiéndose las obras con gran actividad, La Vanguardia, 6 de agosto de 1889 , p.2.
} 
septiembre en Comillas ${ }^{17}$. En el mismo verano, Silvino Thos y Codina constataba también, como hemos visto en el capítulo de Sobrellano, que se estaba procediendo a la construcción de la estatua ${ }^{18}$.

Pero los trabajos ya habían comenzado en Barcelona bastante antes de que Domènech viajara al pueblo de Antonio López. En efecto, una visita de Federico Rahola a los talleres de Francisco Vidal, nos informa de que a mediados de julio de 1889 ya había tenido lugar la fundición de la escultura del primer marqués de Comillas. La obra aparece nombrada junto a la de la estatua de Colón como uno de los grandes hitos de la industria de la fundición en Barcelona, encomiándose su perfección:

(...) Desde el punto y hora en que se propuso fundir grandes estatuas [se refiere a Francisco Vidal] no cejó hasta montar su admirable taller de fundición. Presentóse una ocasión de prueba: la fundición de la gran estatua de Colón y nos asombró la facilidad y perfección con que llevó á término aquel trabajo. Recientemente ha fundido una estatua de Antonio López, obra de Agapito Vallmitjana, para un monumento de Comillas, de tan admirable modo, que, sin retoque alguno, se observa en el bronce hasta la más leve rozadura impresa en el original. Dentro de poco tiempo se fundirá la estatua de Jovellanos, esculpida por Fuxá, destinada á Gijón (... $)^{19}$.

\footnotetext{
17 “Entre los muchos bañistas que se hallan aún en esta villa, figuran el Marqués de Castell Florit, sobrino del General Dulce, las señoras de Tagle, viuda de Brabo é hijas, y las familias del Doctor Losada, Castro Serna y el Arquitecto Domenech". C. "Desde Comillas", Boletín de Comercio, Santander, 8 de septiembre de 1889.

${ }^{18}$ (...) El gótico palacio de los marqueses de Comillas, verdadera mansion señorial, á la vez elegante y majestuosa (...) e1 monumento que la gratitud de 1os santanderinos erige en honor del inolvidable D. Antonio Lopez, todo ha sido y está siendo proyectado, dirigido, construido y ornamentado por arquitectos catalanes, por artistas catalanes $y$, en gran parte tambien, por contratistas y operarios catalanes. Thos y Codina S., “De Comillas á París”, Diario de Barcelona, 26 de octubre de 1889, p. 13129.

${ }_{19}^{19}$ Rahola, Federico “Una visita á los talleres Vidal”, La Vanguardia, 14 de julio de 1889, pp. 4 y 5. Todavía dos años después se recordaría la fundición de la estatua en otro artículo sobre la fundición artística en Barcelona y, en concreto, sobre el taller de Masriera. Siendo éste el sucesor de F. Vidal y Compañía, es lógico que considere la escultura de Comillas obra suya. Así dice García Llansó: (...) A su calor [del desenvolvimiento de la escultura en Barcelona] desarróllanse las industrias artísticas, y especialmente los talleres de fundición de bronces gozan hoy de próspera vida. En uno de ellos, cual es el de Federico Masriera y compañía, ejecútanse en estos momentos la estatua del general Prim, destinada á la ciudad de Reus, la colosal de Hernán Cortés para la patria del conquistador del Perú, otra del malogrado prócer don Evaristo Arnús y un grupo notabilísimo modelado en Alemania que 


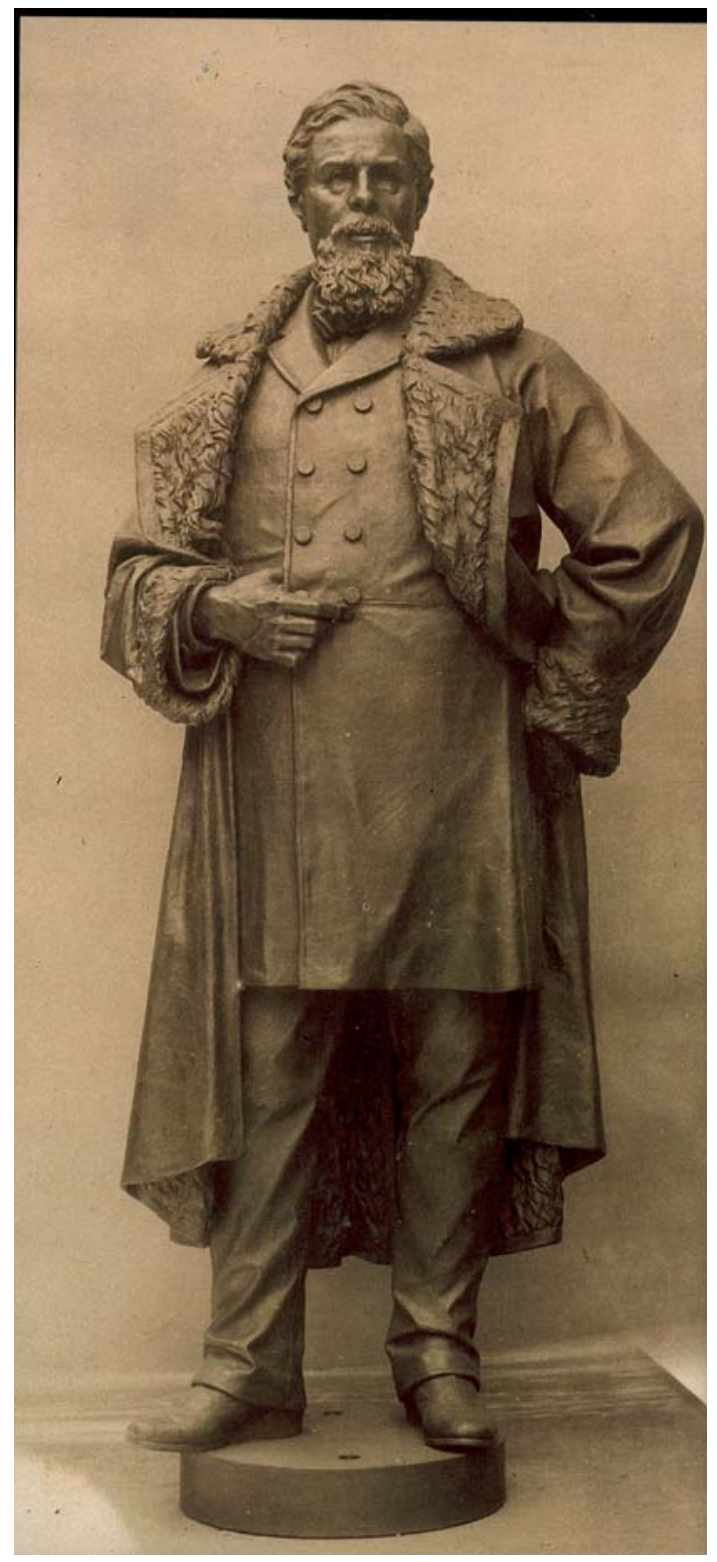

Fig. 5. Agapit Vallmitjana. Estatua de bronce para el monumento a Antonio López en Comillas. Álbum Vidal y $C^{\underline{a}}$

La fecha de fundición de la imagen de Antonio López se podía deducir, de alguna manera, teniendo en cuenta la fotografía de la misma que aparece en uno de los catálogos de la casa F. Vidal y Ca. García-Martín la publicó en su Comillas modernista, aunque sin especificar que era la estatua de bronce del monumento de Comillas ni en cuál de los catálogos que pudo consultar de la firma se encontraba. ${ }^{20}$. Junto con la del bronce, el autor publicaba otras imágenes en las que se pueden ver algunos de los muebles que se hicieron para el Palacio de Sobrellano (hacia 1887) y la portada de uno de los álbumes con la firma de Riquer y la fecha de 1888. Atendiendo al hecho de que la casa F. Vidal y Compañía se disolvio a lo largo de 1889, este año nos daba la fecha ante quem de la estatua.

Algo más de un año después de la noticia que publicara La Vanguardia,

\footnotetext{
ha de emplazarse en una de las plazas de Nueva-York. Y cuenta que en un período de ocho meses se han fundido: dos estatuas de don Antonio López, para Cádiz y Comillas; la de Jovellanos para Gijón, la del marqués de Pontejos y la del Padre Piquer para Madrld, y la de Guarda para la Coruña. (...). García Llanso, A. "Barcelona artística", La Dinastía, 26 de octubre de 1891, pp. 1 y 2.

${ }^{20}$ García-Martín (1993: 224).
} 
la prensa local se hacía eco de la colocación de la escultura en el monumental pedestal:

La estatua del Excmo. Sr. D. Antonio López, primer Marqués de Comillas, quedó instalada ayer sobre el pedestal del monumento erigido en aquella villa á la memoria del ilustre naviero montañés. El suceso no se ha celebrado con festejo alguno, y todavía falta concluir algunos adornos y trabajos complementarios de embellecimiento del sitio en que se destaca el soberbio monumento ${ }^{21}$.

Aunque el periodista dice que no hubo "festejo alguno", sabemos por una curiosa noticia que publicó El Heraldo de Madrid, que estuvo previsto que el Alfonso XIII pasara por delante de la bahía de Comillas para homenajear con 21 salvas al fundador de la Trasatlántica, anticipando así un gesto que se haría después una costumbre 22 .

Una carta de Amanda Pérez a Antonio Correa Pomar, médico comillano destinado a la Compañía de Tabacos de Filipinas en Manila por sus relaciones con los López, nos sirve también de testimonio de la colocación de la estatua y de la ausencia del marqués en el acto ${ }^{23}$. La razón de esta falta total de pompa en la colocación de la estatua es, sin duda, el carácter inacabado de la obra. Entre los "adornos y trabajos complementarios de embellecimiento" que faltaban por concluir, según informaba El Aviso pero sin precisar, estaban, entre otras cosas, las figuras de las "Indias" y los grandes escudos de bronce. Éstas tardarían todavía en colocarse por lo menos dos años. Un "suelto" del Diario de Barcelona informa de su fundición:

\footnotetext{
${ }^{21}$ El Aviso, 22 de noviembre de 1890, núm. 158, p. 2.

${ }^{22}$ Nuestro corresponsal en Santander nos escribe que anteayer causó allí gran disgusto á los pasajeros á bordo de1 Alfonso XIII el ver que éste se alejaba en dirección a la boca del puerto, pues el fuerte viento Norte que reinaba hacia más dificil á los botes la conducción de pasajeros y equipajes al citado buque. Con tal motivo hubo acaloradas disputas entre la oficialidad y el pasaje; y el Alfonso XIII zarpó de aquel puerto á las siete de la noche, en vez de haberlo hecho á las dos de la tarde. Parece que el haberse alejado el citado buque del fondeadero, en donde se hallaba, fué para estimular al pasaje á que apresurase el embarque con objeto de lograr el capitán pasar por delante de Comillas antes de que terminase el día para saludar con 21 cañonazos á la estatua del finado Antonio López que aquel día se descubría con gran solemnidad en esta última población. El Heraldo de Madrid, 23 de noviembre de 1890, p. 2.

23 (...) El dia 19 dia de Sta Isabel colocaron la estatua de Lopez y dice que habia telegrafiado el marques que regularmente bendria pero no vino y creo se fué á Barcelona que estaba en Madrid y fué á pasar dos dias y luego buelbe á Madrid “(...). Carta de Amanda Pérez y Gutiérrez a Antonio Correa Pomar, Comillas 22 de noviembre de 1890. Archivo Correa.
} 
En los talleres de fundicion de la señora viuda é hijos de D. Francisco Cabot se hallaban ayer de manifiesto dos estatuas de bronce de tamaño doble del natural, destinadas al monumento dedicado al Excmo. señor marqués de Comillas que se está construyendo en Comillas. Las dos estatuas simbolizan la una la India americana y la otra el Asia, como recuerdo de las dos líneas de vapores que el difunto marqués fundó para el servicio de las Antillas y de las Filipinas. Estas estatuas han sido ideadas por e1 arquitecto D. Luis Muntaner y Muntaner (sic) y muy bien ejecutadas por el inteligente artista señor Mélida, quien ha sabido interpretar con mucho acierto la idea del señor arquitecto. Los señores Cabot han dejado muy bien terminadas ambas estatuas, hasta en los mas pequeños detalles. Hoy se enviarán á su destino y se empezarán en la referida casa de los señores Cabot 1os trabajos para la fundicion del gran escudo de armas de la familia y la plancha de bronce en forma de lápida que han de decorar otras dos caras del monumento ${ }^{24}$.

Esta noticia confirma, por lo tanto, que en septiembre de 1892 las alegorías de las Antillas y Filipinas se acababan de fundir y no habían sido aún instaladas en el monumento de Comillas. No sabemos cuándo tuvo lugar esta operación, aunque el Diario de Barcelona decía que el envío a su destino era inminente. Lo que sí podemos decir es que la primera vez que encontramos en la prensa alusiones a la obra ya terminada es en el verano de 1893, con ocasión de la visita del Nuncio a la villa cántabra para tomar posesión simbólica del edificio del Seminario. Monseñor Cretoni admira el monumento, y la prensa "descubre", entonces, tanto sus méritos artísticos como los valores paisajísticos de su enclave:

Nuestro diligente corresponsal en Comillas, don Luis Pascual, nos escribe una carta en la cual, ampliando y completando las noticias que nos transmitió por telégrafo, nos dice que el Nuncio de Su Santidad admiró el monumento que,

${ }^{24}$ Diario de Barcelona, 3 de septiembre de 1892, pp. 10207-08. Otro periódico de Barcelona se hacía eco de la misma noticia y profundizaba en el significado alegórico de las esculturas: Han estado expuestas en los talleres de fundición de la señora viuda é hijas de Cabot, las dos estatuas de bronce que se destinan al monumento que se construye en Comillas en honor del difunto señor marqués de este nombre. Dichas estatuas, Que ha ejecutado el señor Mélida segun proyecto del arquitecto don Luis Muntaner, tienen doble tamaño del natural y simbolizan la India americana y el Asia, como recuerdo de las lineas de vapores á las Antillas y Filipinas fundadas por el señor marqués de Comillas. La Dinastía, 5 de septiembre de 1892, p. 2. 
inspirado por el distinguido arquitecto de esta capital don Luis Domenech y cincelado por el escultor senor Mélida, se ha levantado á don Antonio López y López, primer marqués de Comillas. La estatua, que es una obra maestra, ha sido ejecutada en los talleres de don Agapito Vallmitjana.

Levántase el monumento sobre una pequeña colina, desde la cual se puede contemplar uno de los más hermosos panoramas.

Por un lado el Cantábrico que golpea con fiereza ó besa humildemente la costa ya escarpada y llena de peñascos ya mansa formando hermosa y extensa playa en la que se vé un sencillo puerto seco durante la baja mar. Descúbrese sobre éste en una pequeña elevación una fábrica de cordeles y más allá un viejo cementerio de musgosas paredes. A la derecha se vé una fábrica de conservas debida, como la anterior, á la iniciativa y protección del marqués, ávido de desarrollar la industria en su pueblo. Otra fábrica de minerales y una pequeña iglesia que guarda artísticas y veneradas imágenes cierran el panorama.

Por el otro lado presentase un cuadro digno del mejor paisajista. En el fondo de un cielo gris unas veces y de un azul puro y transparente otras y sobre el verde tapiz de las montañas se destacan orgullosos el palacio y la capilla á cuyos pies se hallan los elegantes hoteles de don Eusebio Güell, señoras viuda de López (don Claudio) y baronesa de Satrústegui. A corta distancia se ven multitud de casas viejas unas y recientemente construidas otras, entre las que se ven otros hoteles pertenecientes á distinguidas familias veraneantes $(\ldots)^{25}$.

En una colección particular de Comillas se conserva un cliché o placa de cristal realizado por Romualdo Moro (secretario de Claudio López Bru y aficionado a la fotografía), en el que se ve el monumento en construcción. La esta-

\footnotetext{
25 “Desde Comillas", La Vanguardia, 1 de septiembre de 1893, p. 3. Otra de las crónicas que hablan de los festejos preparados en honor del Nuncio también alude al monumento: “(...) [El] Sr. Iglesias, cumpliendo las órdenes previamente recibidas de don Santiago López, primo del excelentísimo señor marqués de Comillas (quien llegara el miércoles próximo con su bondadosa esposa, procedente de Panticosa) dirigió la banda con la inteligencia que él sabe y tiene bien acreditado. Situada á las doce del mediodía detrás de la hermosa y monumental estatua de bronce sobre gigantesco y emblemático pedestal de piedra, erigida al Sr. D. Antonio López, primer marqués de Comillas, nunca bastante llorado, dominando el puerto y dando vista al mar en direccion á Santander.

Aunque el calor se dejaba sentir demasiado, los habitantes de la población se trasladaron á los terrenos donde está emplazada la estatua, y á las doce en punto se dejaron oir los acordes de un bonito paso doble, que gustó sobremanera. (...)". "El Nuncio en Comillas", La Correspondencia de España, 25 de agosto de 1893 , p. 3.
} 
tua propiamente dicha ya está colocada, pero todavía no los escudos y las "Indias" de bronce. Por lo tanto, la imagen debe de estar tomada entre finales de 1890 y finales de 1892. Además, la placa nos informa de que originalmente había unas jarcias (posiblemente de bronce también) que colgaban desde la base del capitel hasta el dosel circular, así como de que el gran zócalo de piedra aún estaba en proceso de construcción en aquel momento. Este último dato es muy interesante porque demuestra que no se hizo primero el zócalo y después el monumento, como hubiera sido lo esperable y normal, sino que, una vez hecho el pedestal de la estatua y colocada ésta, se procedió a construir aquél.

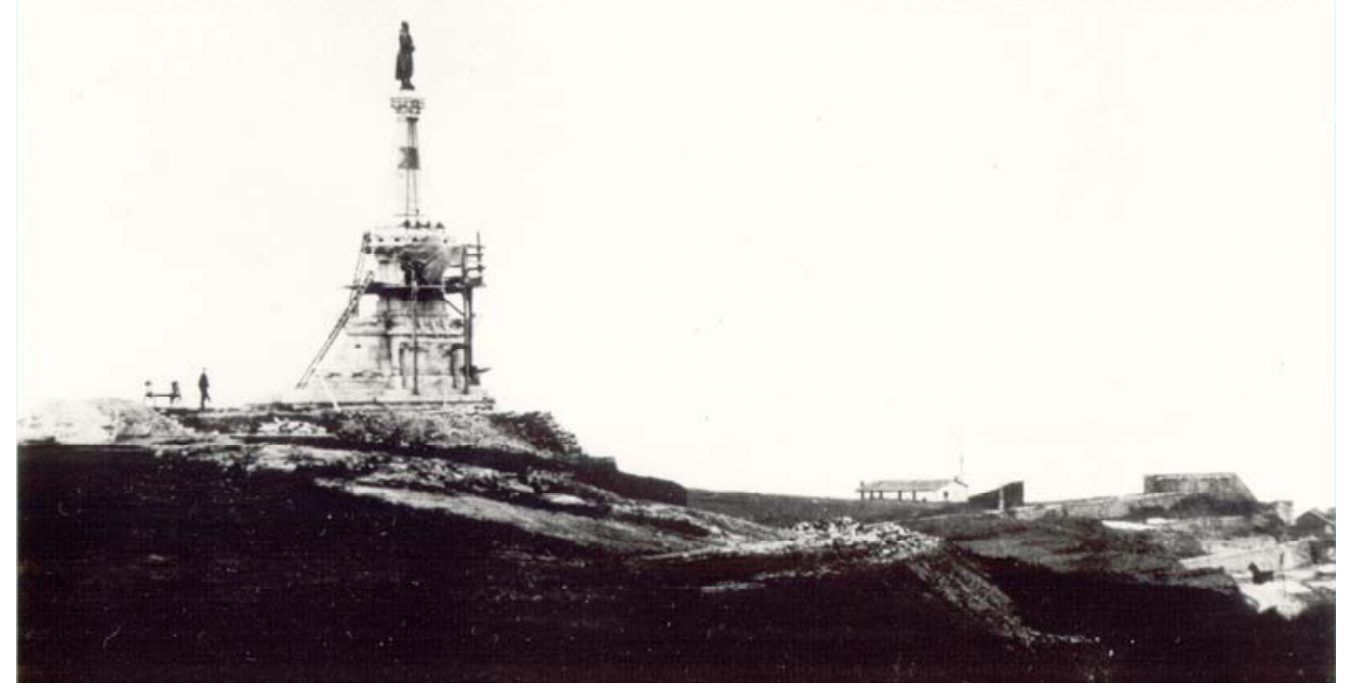

Fig. 6. Monumento a Antonio López en construcción, c. finales de 1890. Fotografía de Romualdo Moro. Colección familiar Val Celis.

De todos los datos aportados, podemos deducir la siguiente hipótesis sobre la génesis y desarrollo del proyecto:

Tras la muerte de Antonio López a principios de 1883, surgen dos iniciativas casi simultáneas en Cantabria para levantar un monumento a su memoria: una en Comillas ( 23 de enero) y otra en Santander ( 1 de febrero). Tras algunos tanteos previos (incluido uno a algún arquitecto francés), el Ayuntamiento santanderino decide encargar el proyecto a Lluís Domènech i Montaner hacia octubre de 1883. A éste correspondería el dibujo conservado en la Cátedra Gaudí, que lleva la inscripción con la fecha (1885) en que se había 
previsto terminar en un principio. A partir de determinado momento, sin embargo, y por motivos desconocidos, se decide aplicar el proyecto concebido para la capital cántabra al de la villa comillana. Sabemos que en septiembre de 1885 Agapit Vallmitjana está modelando ya la estatua. Los periódicos dicen que para un monumento que se está erigiendo en Santander, pero cabe la duda si con este topónimo se refieren a la capital o a la provincia. Lo más probable es que sea esto último, porque en Santander ciudad nunca se empezó a levantar el monumento ni parece que se pagara nunca cantidad alguna a cuenta de los trabajos del escultor. Todo apunta, por lo tanto, a que las obras en Comillas habrían comenzado entrado el año 1885, época por la que Crsistòfol Cascante estaba en la villa dirigiendo la construcción de varios edificios relacionados con la familia y los allegados de los López. No es de extrañar que en esa función de director de obras, se le asignara también la del monumento al marqués para ejecutar el proyecto de Domènech i Montaner. Una anotación en el dietario del primer arquitecto, en la que se lee textualmente "columna de piedra caliza para el monumento", podría aludir a las obras del pedestal y columna de la estatua de Antonio López y corroborar, en consecuencia, esta hipótesis ${ }^{26}$.

En agosto de 1889, tras la muerte de Cascante, Lluís Domènech se hace cargo de las obras y viaja a Comillas para darles impulso pero, aunque la estatua se colocó en noviembre de 1890, éstas no serán acabadas hasta finales de 1892.

Hay que constatar aquí, como ya han hecho todos los autores, que Domènech introduce en la obra definitiva algunos cambios con respecto al proyecto primigenio. Los más visibles afectan a la columna, que en su forma final es más esbelta y menos troncocónica. Del fuste han desaparecido los cordelajes, de manera que su superficie es lisa y sólo está interrumpida por un anillo de azulejos azules que enmarcan un círculo blanco con el monograma de Antonio López. El capitel ha perdido sus querencias corintias y presenta una decoración mucho más estilizada a base de prismas romboidales. La esculturación cordiforme ha dado lugar a las jarcias metálicas visibles en la fo-

\footnotetext{
${ }^{26}$ La anotación aparece en una hoja con referencias al Palacio y dibujos relacionados con el Seminario, entre otros. La vaguedad de la frase da lugar a dudar de si en realidad esa columna a la que alude Cascante es la del hito conmemorativo de las visitas de Alfonso XII a Comillas, pero ésta parece de naturaleza marmórea, no caliza.
} 
tografía antes mencionada (sus puntos de anclaje todavía son visibles en el capitel y el voladizo circular). También ha desaparecido la inscripción con la dedicatoria, y ha sido sustituida por una especie de guirnalda vegetal.

La modificación más importante, con todo, consistió en el añadido de un gran zócalo de mampostería que salva el desnivel del terreno en la vertiente norte. Tiene planta de forma paraboloide y una escalera anular soportada en grandes arcos ciegos. Sin duda, es un gran hallazgo de Domènech porque realza enormemente el monumento, sobre todo visto de lejos.

Constatadas las reformas, queda pendiente determinar cuándo se produjeron aquellas. Es lógico pensar que las que afectaron a la columna estarían ya previstas por lo menos desde el verano de 1889, si no antes ${ }^{27}$, ya que cuando se coloca el bronce de Antonio López el 19 de noviembre de 1890, aquella responde al modelo ya reformado. Las jarcias esculpidas han sido sustituirlas por otras más "realistas" en forma de cadenas metálicas colgantes. Sin embargo, la construcción del zócalo debió ser una decisión de última hora, tomada alrededor del año 1892 como demuestra la fotografía de Romualdo Moro. Para ello fue necesario hacer un gran desmonte de terreno, pues la misma fotografía atestigua que allí no había un desnivel tan acusado ${ }^{28}$.

Debemos pensar que la razón de esta reforma es la de adecuar el proyecto primero - pensado para un entorno urbano- al contexto paisajístico donde finalmente se decidió ubicar el monumento. El lugar elegido fue un promontorio elevado sobre el litoral desde el que se abarcaba un amplio panorama marítimo ${ }^{29}$. Además de por sus connotaciones simbólicas asociadas al personaje, el empla-

\footnotetext{
${ }^{27}$ La estatua de Antonio López, según se ve en la imagen del catálogo de F. Vidal y Cia o en las postales antiguas del monumento, también fue modificada notablemente con respecto al proyecto conservado en la Real Cátedra Gaudí. Si tenemos en cuenta que en septiembre de 1885 Agapito Vallmitjana ya esta modelando el barro, hay que concluir que la modificación tuvo que hacerse en aquella época.

${ }^{28}$ Las obras debieron ser importantes y ocupar a bastantes operarios, pues Ortiz de la Azuela (1902: 78-79) comenta que al terminarse las obras de su palacio, del Seminario y del costoso pedestal que por suscripción de los amigos se construía para colocar la estatua de su dicho padre y ver que no reunía el pueblo elementos suficientes para dar ocupación á tanto artesano, es cuando decidió Claudio López Bru instalar una serie de industrias en Comillas para ofrecer trabajo a los obreros parados.

${ }^{29}$ Según Arnús (1999: 99), el terreno fue donado por Ángel Pérez al pueblo para levantar el monumento.
} 
zamiento estaba pensado para que los buques de la Trasatlántica divisaran de lejos la estatua a su paso por la costa comillana. El discreto pedestal de la primera versión debió de parecer insuficiente a Domènech para cumplir este condicionante del programa y decidió realzar el monumento con el gran zócalo que lo hace mucho más visible en lontananza, como un faro volcado hacia el mar.

Como hemos visto, en el pedestal figura esculpida la fecha de 1890. Ese debió ser el año previsto por Domènech para la terminación del monumento pero, aunque la estatua se colocó efectivamente a finales de aquel año, la finalización definitiva de los trabajos no se produjo hasta finales de 1892. No sabemos cuál fue la razón de tal retraso pero, dado que las obras se llevaron a cabo por suscripción de los amigos según comenta Ortiz de la Azuela, es posible ver en ello razones de índole económica.

De acuerdo con nuestra hipótesis, por lo tanto, la autoría del primer proyecto habría que atribuirla a Domènech y no a Cascante. Sin embargo, es cierto que el dibujo de la Real Cátedra Gaudí adolece de cierta rigidez, impropia del virtuosismo gráfico del profesor de la Escuela Provincial de Arquitectura, y que el diseño, como apunta Oriol Bohigas, es bastante impersonal ${ }^{30}$. Una explicación plausible de estas incongruencias es que se tratara de una colaboración Domènech-Cascante, de la misma manera que en el Seminario se produjo una Martorell-Cascante. Es decir, que el primero podría haber hecho un croquis y el segundo lo habría concretado y dibujado para presentarlo al Ayuntamiento de Santander ${ }^{31}$.

La atribución a Domènech del proyecto original, por otro lado, puede verse reforzada por el hecho de que no hay ningún testimonio coetáneo que mencione a Cascante como autor del monumento (hay que esperar al año 1971 para que Juan Bassegoda se lo adjudique), mientras que la prensa del momento señala claramente al arquitecto del Palau de la Música como respon-

\footnotetext{
${ }^{30}$ A més del seminari, Domenech va projectar el 1890 un monument al primer marques en un penyasegat sobre el mar, en un estil bastant eclectic i impersonal. Bohigas, Oriol: "Lluís Domènech i Montaner. Architecte modernista", en Lluís Domènech i Montaner. En el primer aniversari de la seva mort (1850-1923), Barcelona, 1973, p. 40.

31 No obstante, el dibujo del monumento tampoco parece corresponder al estilo de Cascante, quien, por otra parte, no era mal dibujante. ¿Podría ser aquel el proyecto para Santander del arquitecto francés? No sería descartable que el marqués hubiera encargado a Cascante / Domènech la adaptación de aquel proyecto al enclave comillano.
} 
sable del mismo, tanto en 1883 como en 1889 y 1893. Además, hay que señalar que por lo menos en una de las primeras necrologías publicadas después de la muerte de Domènech i Montaner, se le reconoce claramente la autoría tanto del proyecto como de la ejecución del memorial comillano. Así, Benito Guitart (1924: 6) dice haciendo un repaso de sus obras:

Proyectó y ejecutó varios monumentos: el mausoleo del músico poeta Clavé, en colaboración con D. José Vilaseca; el de la familia Piélago y el del primer marqués de Comillas, en esa población, y los monumentos funerarios de Jaime I el Conquistador, y para los reyes e infantes sacados del monasterio de Poblet, en la catedral de Tarragona.

El mismo monumento funerario para Jaume I al que alude Guitart, aunque de fecha mucho más tardía, podría considerarse también como un argumento a favor de la autoría de Domènech, puesto que en éste emplea el arquitecto el mismo recurso de la doble proa que hemos constatado en Comillas, para cerrar por ambos lados la base de la fábrica ${ }^{32}$. Por otro lado, y como veremos después, un mismo concepto del símbolo y de la decoración icónica parece estar presente desde el Monumento a Clavé (1877) hasta el de Tarragona, pasando por el de la villa de Antonio López.

De cualquier modo, y si en la cuestión de la atribución del proyecto puede caber algún pequeño interrogante todavía, la documentación que hemos presentado no deja lugar a dudas sobre la identidad de casi todos los agentes participantes en la realización de la obra. Por un lado, se ha confirmado la paternidad de la estatua del marqués a favor de Agapit Vallmitjana. Esta era una atribución generalmente admitida (aunque a veces se ha hecho a favor de su hermano Venanci), pero sin ningún tipo de justificación documental. Lo mismo ocurría con las imágenes de bulto redondo de las "Indias", adjudicadas por lo general a Arturo Mélida pero sin citar las fuentes que lo acreditaran ${ }^{33}$. La presencia de Mélida en el monumento está plenamente justificada por la amistad

32 Este recurso también se puede ver, por otro lado, en las "quillas" del monumento en recuerdo de la catástrofe del Machichaco, en Santander (cfr. Bermejo, 1998: 168).

33 Éstas debieron ser la "nota necrológica" aparecida en el Anuario para 1903 de la Asociación de Arquitectos de Cataluña, 439-443, firmada por "L.D.M.", sin duda Lluís Domènech i Montaner. Allí se dice textualmente: Para el monumento a Antonio López en Comillas hizo también dos estatuas de la América y la Oceanía españolas, de carácter arcaico propio de aquellos paises, y los leones decorativos. 
que le unía a Domènech i Montaner desde que ambos fueran condiscípulos en la Escuela de Arquitectura de Madrid ${ }^{34}$. Como hemos visto anteriormente, el arquitecto y escultor estaba muy interesado en las artes industriales y había ayudado a Domènech en su proyecto del Castell dels Tres Dragons.

Por otro lado, la prensa catalana nos ha brindado la oportunidad de conocer dónde se fundieron los bronces: el de la estatua del marqués en Francisco Vidal y Compañía y los de las alegorías de Las Antillas y Filipinas en la fundición de Viuda é hijos de D. Francisco Cabot. El único dato que falta es el referente a los escultores que trabajaron en el pedestal y la columna. Ya hemos visto que los leones son también del propio Mélida pero, a título de hipótesis, podemos considerar como bastante probable la intervención de Luis Ferreri, escultor adornista que hizo las placas de mármol situadas en la fachada de la Capilla-Panteón y que colaboró con Martorell en otras obras ${ }^{35}$. Al parecer,

${ }_{34}$ Arturo Mélida y Alinari (Madrid 1849-1902) se licenció en la Escuela Especial de Madrid en 1873. A partir de entonces desarrolló una fecunda carrera no sólo como arquitecto, sino también como escultor y pintor, una multidisciplinaridad que le hizo acreedor en su tiempo del apelativo el Miguel Ángel del siglo XIX. En 1877 ganó el concurso para la construcción del monumento a Colón de Madrid, resuelto en estilo neogótico. Sus obras de arquitectura más famosas son la aludida Escuela de Artes Industriales de Toledo (proyectada bajo la influencia que le había reportado la restauración de San Juan de los Reyes) y el Pabellón de España en la Exposición Universal de París de 1889, por la que recibió la medalla de oro. Como pintor participó en la decoración de muchos de los palacetes de la nobleza madrileña, en la del Museo del Prado y en la del Ateneo de Madrid. También fue ilustrador de libros, particularmente de las obras de Benito Pérez Galdós. Desde 1879 ocupó la plaza de profesor de modelado en la Escuela de Arquitectura de Madrid, y en 1899 ingresó como académico de número en la Real Academia de Bellas Artes de San Fernando. Sobre Arturo Mélida se puede ver: Moya Idígoras, Juan, “En el centenario de D. Arturo Mélida y Alinari (1849-1902)", Academia, Madrid, 1951, pp. 3-8. En esta obra se citan como obras suyas las estatuas de América y Oceanía en el monumento al Marqués de Comillas, por Domenech (p. 60); Navascués, Pedro, "Arturo Mélida y Alinari, 1849-1902", Goya, núm. 106, Madrid, 1972, pp. 234-241; Casado Rigalt, Daniel (2006): José Ramón Mélida (18561933) y la arqueología española, volumen 13 de Publicaciones del Gabinete de Antigüedades de la Real Academia de la Historia, Antiquaria Hispánica, 13, Madrid.

${ }^{35}$ Las primeras noticias que tenemos de Luis Ferreri datan de 1864, cuando comienza a trabajar en la decoración de la Universidad de Barcelona junto con un nutrido grupo de escultores entre los que figuran sus hermanos José y Enrique (Cfr. Elies Rogent i la Universitat de Barcelona, Edicions Universitat Barcelona, 1988, p. 154.). Antes, sin embargo, una noticia aparecida en el Diario de Barcelona con fecha de 17 de septiembre de 1863 (AC), daba cuenta de que "Los escultores Casañas y Ferreri han abierto una tienda de objetos de mármol en la calle del Pino", y suponemos que se refería al mismo artista. Según las notas manuscritas del archivo Antonio Correa,

Arte y Ciudad - Revista de Investigación 
Ferreri se quedó a vivir en Comillas después de su participación en varios de los monumentos erigidos al calor del patrocinio de los López, y fue el autor de algunas de las lápidas del cementerio parroquial ${ }^{36}$. Como veremos más adelante, dedicó una fotografía del panteón Piélago a Domènech, por lo que debió de tener buena relación con el arquitecto.

\section{Simbología del memorial a Antonio López.}

El monumento al primer marqués de Comillas tiene, como es propio de la arquitectura conmemorativa, un carácter eminentemente simbólico. Lo habitual es que, mediante el uso de un programa iconográfico diseñado al efecto, se representen simbólicamente las ideas y los hechos relacionados con el homenajeado. Así ocurre en la obra proyectada por Domènech para Comillas, pero en este caso la elección del emplazamiento adquiere, además, unas especiales connotaciones simbólicas tan importantes o más que el lenguaje icónico.

Debido al gran crecimiento urbanístico que ha venido sufriendo Comillas a lo largo de las últimas décadas, hoy quizás no seamos conscientes de la estrecha relación que hay (o había) entre el mar y el monumento. Cuando todavía no había prácticamente ninguna edificación en la línea de costa ni existía la carretera que bordea ésta y lleva al puerto, la estatua se veía volcada al mar y situada muy cerca del muelle. De esta manera Domènech (y seguramente también los suscriptores del monumento) se proponía subrayar la relación del ilustre comillano con el mar y con la actividad naviera que fue el origen de su

entre 1877 y 1882 trabajó con Joan Martorell en la iglesia de Las Salesas y posteriormente, desde 1882 a 1894 colaboró también con el maestro en la de los jesuitas de la calle Caspe. Otra participación más de Ferreri en obras de Martorell registrada por Correa es el altar de la Virgen de Montserrat de la Catedral de Barcelona, entre 1889 y 1890. Finalmente, La Vanguardia del 28 de agosto de 1896 le cita como el escultor del edificio "Gas Lebon" en Barcelona. Según Ràfols en su Diccionario de Artistas de Cataluña, p. 398, Luis Ferreri tenía en 1900 su taller en la calle del Consejo de Ciento, 298. de él dice que fue "escultor decorador del siglo XIX-XX, de Barcelona", dedicado a "trabajos artísticos en barro, yeso, piedras y mármoles para decoración de fachadas, panteones, altares y al ramo de obra en general".

${ }^{36}$ Antonio Correa, notas manuscritas. En el mismo documento se dice que las hijas de Ferreri vivieron durante muchos años en Comillas. Como hemos visto anteriormente, el escultor debió de alternar su residencia en la población cántabra con la de Barcelona, donde trabajaba esporádicamente y mantenía un estudio. Quizás hacia 1900 se trasladara definitivamente a la Ciudad Condal. 
fortuna. Integrando el paisaje litoral como parte consustancial del monumento, el gran arquitecto parecía contradecir polémicamente al otro memorial levantado por Oriol Mestres en Barcelona, del que se había criticado precisamente que estuviera de espaldas al cercanísimo mar $^{37}$. Pero hay que tener en cuenta además que la estatua no debía estar sólo próxima a la costa, sino que también debía de ser divisable desde los vapores de la Trasatlántica que surcaban las aguas comillanas.

Estos valores simbólicos fueron agudamente percibidos por Alfonso Pérez Nieva, que en 1893 nos dejó las que posiblemente han sido las mejores descripciones del monumento. La primera de ellas, publicada en El Globo, dice así:

Se yergue sobre un bello pedestal de piedra, en el que están simbolizados los diferentes atributos de la industria naviera, y en la cúspide de una columna, como "nuestro madrileño" Colón; la estatua es de bronce y aparece vestido con gabán de pieles. El monumento se halla enclavado sobre un montículo, á la orilla del Cantábrico, como dominándole.

Ha sido una felicísima idea la de alzar esa estatua frente al mar. El hombre que unció á su carro de triunfo las olas, debía de ser inmortalizado de tal manera. En vida las olas rompieron millares de veces contra los cascos de sus buques; después de muerto, las mismas olas llegan á salpicar la base del monumento, erigido á la memoria del gran patricio, á darle todos los días un beso de hermano que no olvida.

Don Antonio López amaba el mar con la pasión del que ha sentido volar sus ilusiones juveniles desde la cubierta de un barco. Quizás hubo en su vida dos mecimientos inolvidables: el de su cuna y el de sus vapores; el que procede de la mano de una madre y el que procede de la mano de Dios.

Dejándose llevar de su voluntad de hierro, y ahondando en el porvenir con su mirada profunda, fundó un día la empresa naviera que es hoy honra de España y que conduce nuestro pabellón mercante á todas partes. El Océano, para tantos implacable verdugo, fue para él dócil y sumiso é hizo su fortuna, engrandeciendo de paso el nombre de su patria.

\footnotetext{
37 Durante el dia de ayer fue excesivo el número de curiosos que acudió á contemplar el monumento inaugurado el Sábado último al insigne naviero don Antonio Lopez Lopez, primer marqués de Comillas, siendo no pocos los que censuraban que la estatua de dicho señor no mire hácia el mar, hallándose colocado junto á él y sin obstáculo que se lo impida, máxime cuando al comercio marítimo debió don Antonio Lopez su justo renombre y su opulencia. La Iberia, 15 de septiembre de 1884, p. 5.817.
} 
Por prescripción reglamentaria, cuantos vapores de la Trasatlántica salen de Santander con rumbo á América, saludan al monumento con dos cañonazos al pasar ante él, rindiendo así un justo tributo al que fue la piedra miliar de la Compañía; es un acatamiento de hijo á padre. Si fuera fácil entonces trepar á lo alto de la columna, veriáse á la estatua iluminada el rostro de júbilo y sonriendo satisfecha con sus labios de bronce. Es una felicidad póstuma. Don Antonio López vive gozoso la vida etérea de la inmortalidad en ese lugar de la costa, desde donde presenciará eternamente el tránsito de sus buques queridos ${ }^{38}$.

La segunda de ellas, aparecida pocos días después en La Dinastía, complementa la primera en el mismo tono de poético entusiasmo que le suscita "La estatua":

(...) Comillas es la segunda ciudad española donde se levanta un monumento á don Antonio Lopez: Se imponía el lugar para la creación de la estatua y próximo al hermoso puertecito se alza á la misma orilla del mar, de tal suerte que los buques de la Trasatlántica de la que él fué la piedra miliar robusta y gigantesca, saludan con sus cañones la memoria del noble patricio, siempre que en su viaje á América aciertan á pasar por delante de aquella figura de bronce erguida en medio del campo.

El monumento es sencillo y elegante. Constitúyenle en su parte esencial varias popas de barco de piedra que forman su basamento y le adornan en artísticos grupos multitud de atributos marinos; la estatua de bronce, vestida con largo abrigo, de severa y reposada actitud se alza en lo alto de una larga y esbelta columna. Bastantes millas mar adentro se descubrirán la columna y la estátua por cuantos navegantes, extraños y propios cruzen (sic) el Cantábrico. El nombre de Lopez no dejará, por ende, de ser pronunciado sobre la inmensa llanura de las olas, mientras surque las aguas salobres un buque, y se divise desde cubierta el monumento de Comillas (... $)^{39}$.

El corresponsal de La Vanguardia destacado para cubrir la visita del Nuncio, también había comprendido las virtudes paisajísticas del lugar, las mismas que todavía hoy saben apreciar los comillanos o los veraneantes, que hacen del parque que hoy rodea al monumento uno de los lugares preferidos para disfrutar del magnífico panorama de este rincón de la costa cantábrica.

38 Pérez Nieva, Alfonso (1893, 3 de septiembre, p. 1).

39 Pérez Nieva, Alfonso (1893, 18 de septiembre). 
Pero lo que ni este periodista ni Pérez Nieva podían sentir es el valor emocional que representaría para los que vivieron las Jornadas Regias de 1881 la elección de aquel lugar. Todo indica, en efecto, que se trata del mismo donde estuvo enclavado el kiosco de María Cristina, el pabellón de madera desde el que Alfonso XII asistió impresionado al desfile naval organizado en su honor por Antonio López ${ }^{40}$. Aquel sitio se llamaba la Cruz Verónica y, como demuestra la parte correspondiente del friso del Salón de Recepción de Sobrellano, pasó a convertirse en uno de los principales escenarios de la apoteosis del primer marqués de Comillas. Erigir allí el monumento suponía, de alguna manera, petrificar aquel momento de gloria y hacer eternamente recurrente aquel homenaje naval.

Por lo demás, el discurso icónico del memorial es directo y sencillo. Esta simplicidad casi ingenua no hace sino aplicar en la práctica un concepto del simbolismo que dejara claramente expuesto Domènech i Montaner junto con su colega Josep Vilaseca en la memoria del proyecto para el monumento a Clavé:

Tal vez nos engañemos, pero este simbolismo que se concreta en amontonar objetos conocidos con el nombre de atributos lo encontramos indigno de la arquitectura por su mezquindad. Puede suceder en cosas momentáneas y cuando los objetos que forman el atributo son verdaderos y reales, pero al esculpir en una piedra las formas estilizadas y utilitarias de los objetos reales, pierde aquélla su carácter de fuerza y por consiguiente de duración y, lo que es peor, pierden los mismos atributos de tal modo sus caracteres distintivos que hasta nosotros, los que por nuestra profesión estamos acostumbrados a tratarlos, muchas veces no los reconocemos. Y en cuanto al simbolismo convencional de las plantas, los encontramos todavía más desprovisto en general de sentido; porque en su mayor parte tiene fundamentos muy remotos y solamente en algunos casos es por todo el mundo reconocido porque es verdadero y resultado de una comparación tan exacta como poética. En una palabra, el simbolismo para nosotros es necesario que se sienta, que se adivine vagamente, y se desprenda sin que el es-

${ }^{40}$ Para agasajar a su ilustre huésped y hacer ostentación al mismo tiempo de su poderío económico, el magnate comillano ideó una especie de parada naval frente a las costas de su villa natal. El acto tuvo lugar el 26 de agosto de 1881 y dejó una honda impresión tanto en Alfonso XII como en la opinión pública: frente a la bahía de Comillas desfilaron perfectamente empavesados 6 vapores de la Compañía Trasatlántica con casco de acero. Los monarcas y la corte contemplaron el insólito espectáculo desde el kiosco de la Cruz Verónica. 
pectador tenga que hacer ningún esfuerzo, sin tener que darle una lección, para entenderlo, del "Lenguaje de las flores" u otra obra trivial o por el estilo. La Edad Media nos proporciona bellos ejemplos de simbolismo, siempre tratados con sobriedad y el lenguaje severo y estilizado de la arquitectura y solamente en este género creemos que se puede admitir en el campo del arte. Comprendemos que es más difícil más vago, más revesado de hablar para que sea comprendido con claridad, pero a él hemos creído que nos debíamos de ajustar... ${ }^{41}$.

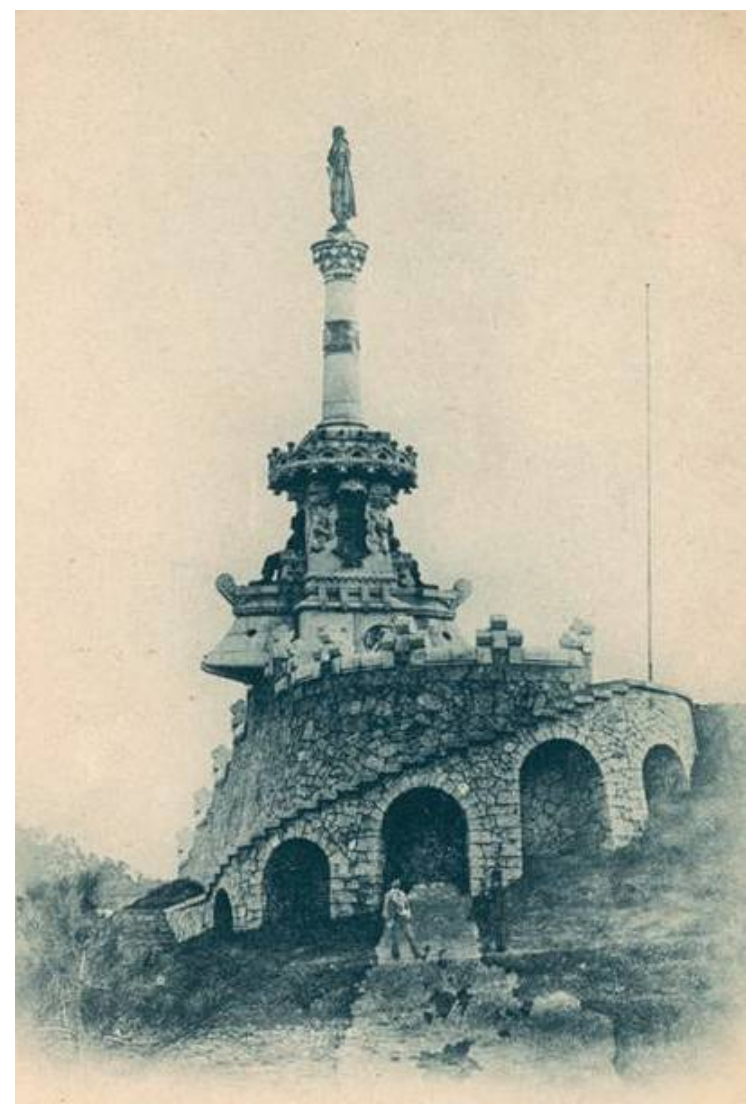

Fig. 7.

El Monumento a finales del siglo XIX. Postal Gregorio García.

${ }^{41}$ La transcripción la hemos tomado de Figueras, Lourdes (1990a): “A la búsqueda de una identidad. El monumento a Clavé", en Lluís Domènech i Montaner. Arquitecto modernista, Barcelona: Fundación Caja Barcelona, pp. 49-51. El texto original en catalán de la memoria fue reproducido, con algunas modificaciones de los autores, en la revista La Renaixensa, Año V, núm. 10, 28 de febrero de1875, pp. 341-346. Lleva el título "Lo monument á Clavé" y está firmado por Domènech y Vilaseca en noviembre de 1874. 
Así, las alusiones evidentes a la arquitectura naval como emblema del imperio económico de Antonio López son la base del programa simbólico. Lo que primero llama la atención es la doble proa de la base del pedestal, orientada en dirección al mar, como dispuesta a surcar las procelosas aguas del Cantábrico. Unas pequeñas ondas marinas muy estereotipadas, esculpidas en la parte inferior de las proas, quieren sugerir el efecto rompe-olas que producen las naves en su singladura. Un áncora dentro de un círculo refuerza las connotaciones marineras del monumento.

Según Aramburu-Zabala (2007: 412), la forma de esta base tendría su fuente de inspiración en la 'Victoria de Samotracia', conservada en el Louvre, monumento conmemorativo de una victoria naval en la época helenística. Es posible, pero la epopeya de Antonio López no está vinculada a la gesta bélica (si bien es verdad que el papel de su naviera en la guerra de Cuba fue fundamental), sino al comercio naval. Por ello, consideramos más probable que la fuente iconográfica de la base del pedestal sea el motivo de "rostro" que ya hemos visto empleado por Martorell en la fachada del Palacio de Sobrellano en el mismo sentido de icono de la navegación comercial y pacífica. La presencia del ancla, por otro lado, es totalmente coherente con este programa simbólico puesto que, además de ser el emblema marinero por excelencia, es uno de los iconos más repetidos en la imaginería relacionada con el marqués de Comillas (véanse los escudos del Palacio y del Seminario). Pero es interesante destacar, además, el parecido de este áncora encerrado en un círculo con el que aparece en la base de las farolas de la Plaza Real diseñadas por Gaudí (1878).

La iconografía naval se continúa en las jarcias que se habían previsto esculpidas en la columna según el proyecto original, pero que luego fueron concebidas como catenarias colgantes de bronce o hierro. Esta última solución daba mucho más peso "visual" a este elemento asociado indisolublemente a la imagen de los barcos de vela. Esto es un ejemplo de cómo Domènech i Montaner sacrifica el "realismo" histórico en favor de un simbolismo primario que emplea los arquetipos del imaginario colectivo para una mejor comunicación del mensaje simbólico. En efecto, se trataba de transmitir al espectador de la manera más sencilla la epopeya de aquel humilde cántabro, originario de una pequeña población marinera, que llegó a convertirse en el dueño de un verdadero imperio naval. Pero un imperio naval que encontró su vía de crecimiento precisamente en el aprovechamiento de lo que por entonces era la 
nueva tecnología de la navegación a vapor, superando así la eólica que, ya por aquella época, comenzaba a estar anticuada.

Sin embargo, el arquitecto no ha renunciado a emplear la iconografía tradicional vinculada a la arboladura de los barcos de vela para hacer más comprensible el mensaje entre sus contemporáneos.

A diferencia del monumento de Oriol Mestres, se han eludido en éste de Comillas las referencias explícitas a los diferentes negocios del marqués, para centrar así toda la carga simbólica en la dimensión oceánica del origen de la fortuna y fama del homenajeado. Las estatuas sedentes de Las Antillas y Filipinas, por lo tanto, no representan tanto el negocio naviero y el de tabacos, como las principales líneas de los vapores de la Compañía Trasatlántica ${ }^{42}$. Los continentes de América y Asia aparecen de este modo como los dos extremos del imperio naval levantado por Antonio López. Como colofón de esta iconografía naviera, la franja de azulejos azules y blancos que decora el fuste de la columna con las cifras "AL", exhibe los colores corporativos de la compañía de vapores fundada por el marqués. Se funden así la enseña de la Trasatlántica con las iniciales de su fundador para formar un emblema que resume el discurso simbólico del monumento.

Otro nivel significativo que no podía faltar en el memorial comillano es el heráldico, y a él corresponde el escudo de bronce del marquesado flanqueado por los expresivos leones rampantes, animales heráldicos por excelencia que aquí también podrían ser una apropiada alusión a la fiereza empresarial de este montañés de genio, forjado a sí mismo en la dura batalla comercial. Lamentablemente, no conocemos la inscripción que habría en la placa que hacía de pareja del escudo por la otra cara del pedestal. Es posible, sin embargo, que reflejara el acta municipal por la que se decide erigir el monumento. Finalmente, consideramos también de naturaleza cuasi-heráldica el dosel circular que cubre el pedestal. Como hemos indicado, su faldón ha sido diseñado de una forma que parece querer evocar por empatía el aspecto de una corona marquesal con sus puntas.

\footnotetext{
42 Por su forma y colocación, “Las Indias” recuerdan las alegorías sedentes que en el pedestal del monumento a Joan Güell y Ferrer (Barcelona), representan la Agricultura, la Ganadería, la Navegación y el Comercio, y las Artes. El monumento a Güell fue proyectado y dirigido por Joan Martorell i Montells. Se inauguró el día 7 de junio de 1888, en plena coincidencia con la Exposición Universal de Barcelona.
} 

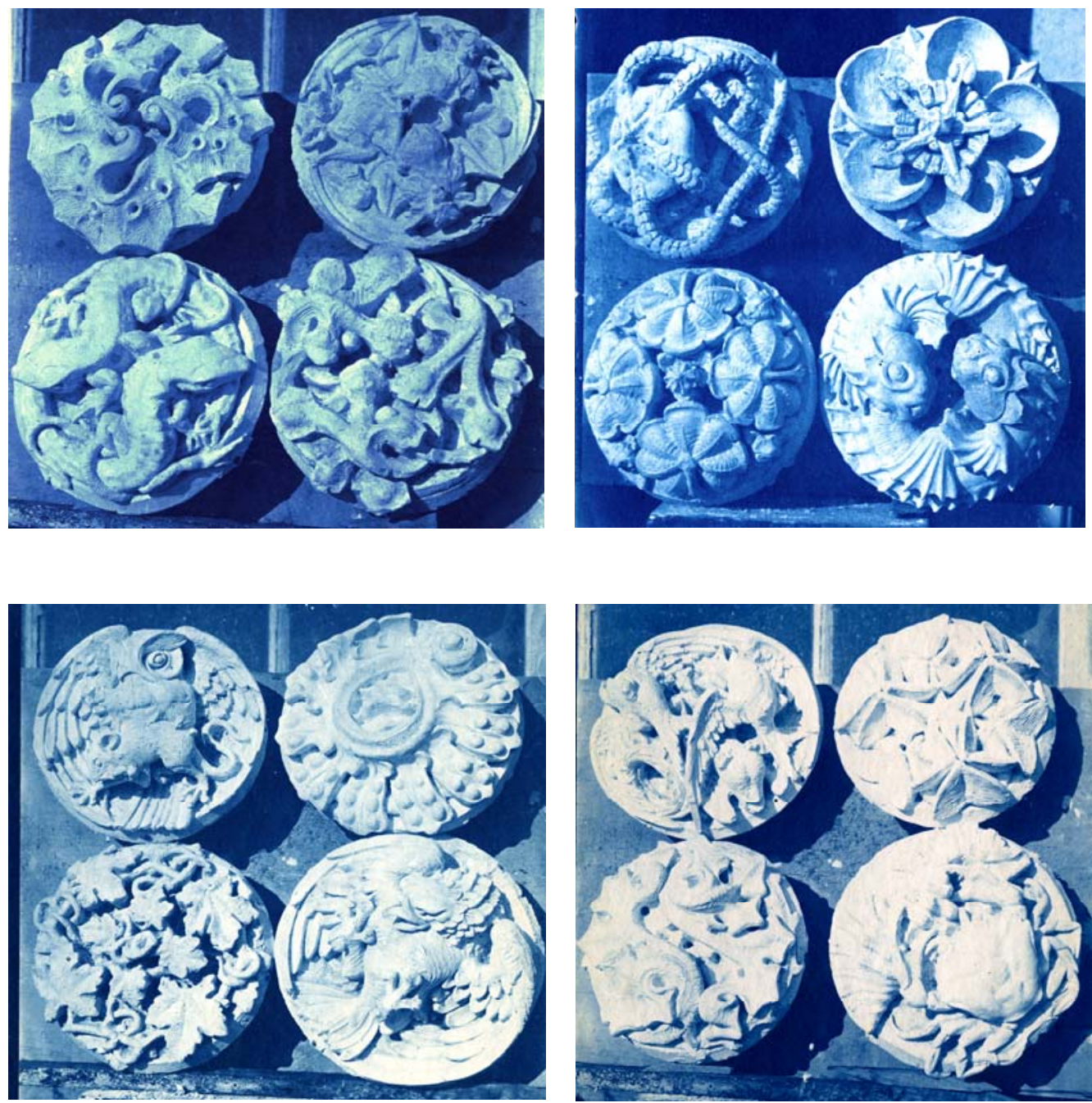

Fig. 8. Modelos en yeso de los discos decorativos del Monumento a Antonio López en Comillas. AHCOAC (autor desconocido)

Pero además del naviero y del heráldico, hay un tercer nivel simbólico en la obra de Domènech i Montaner que es menos evidente y está enclavado en lugares del monumento más recónditos. Los iconos de este programa se sitúan en unos discos o medallones que cuelgan del borde interior del referido dosel, y en los intersticios que quedan entre el voladizo de éste y el pedestal. En el fondo "Domènech i Montaner" del COAC hay unas fotografías viradas 
hacia tonos azulados en las que aparecen los yesos que sirvieron de modelos para el esculpido de estos discos ${ }^{43}$. Se distinguen en ellas hasta 15 motivos distintos que se corresponden exactamente con los que decoran actualmente "La estatua". En cada una de las fotografías se retratan cuatro de estos discos, decorados con motivos zoomorfos y fitomorfos. Los primeros son más fáciles de identificar, y entre ellos hemos reconocido: una lechuza con un ratón; un ave que podría tratarse de un águila o quizás mejor, de un milano (Milvus migrans); pájaros con cola ahorquillada (¿golondrinas, alondras?); murciélagos; lagartos o salamandras; un cangrejo de caparazón trapezoidal (Carcinus maenas); una estrella de mar del tipo ofiuroideo, con largos brazos en forma de tentáculos, y dos peces de aspecto encrespado como los que habitan los fondos rocosos (posiblemente se trate de cabrachos o Scorpaena scrofa, de cabras o Serranus cabrilla, o bien del típico pez de roca Coryphoblennius galerita). Entre las especies vegetales hemos reconocido la hoja de parra, la pasionaria (Passiflora caerulea), un alga del tipo Focus vesiculosus (sargazo vejigoso) y unas flores que quizás correspondan a la Euphorbia paralias. Otras formas vegetales podrían responder al acanto o diversos tipos de helechos, pero no hemos podido identificarlas con precisión ${ }^{44}$.

La primera cuestión que suscita la presencia de estos discos esculturados es, obviamente, si responden a un mero afán decorativo o si, por el contrario, se incluyen como parte de un programa iconográfico concreto. Pero a poco que analicemos críticamente los especímenes de la fauna y la flora representados, convendremos en la certeza de esta segunda posibilidad. Todos los motivos zoomorfos, en efecto, podemos decir que están presentes en el ecosistema de la geografía comillana, desde la parte más interior que abarca Ruiseñada y la zona limítrofe con Udías, hasta la franja litoral que se prolonga hasta la ría de La Rabia y la playa de Oyambre. Domènech ha tenido la precaución de recoger tanto las especies de la fauna terrestre como de la marina. Así, por

${ }^{43}$ COAC, Fondo Domènech i Montaner, carpeta C 1663/21 "Monumento a Antonio López". Cuatro fotografías de los yesos tomadas probablemente en el taller del escultor.

${ }^{44}$ Es posible que uno de los discos de iconografía dudosa presente la característica especie en forma de estrella conocido como "anís estrellado" (Illicum verum) que produce el Badian, árbol oriundo de China y otros países del Sur de Asia como Vietnam o Filipinas. No podemos descartar que la presencia de esta exótica especie en el monumento se deba al arraigo de algún árbol de este tipo en la villa de Comillas dada la relación de los marqueses y de otros comillanos con el archipiélago asiático. 
ejemplo, el milano es muy representativo de la zona de Ruiseñada y los cangrejos, estrellas de mar, etc., son propios de la zona submareal de la misma costa de Comillas o de Oyambre. La flora alude sobre todo a la vegetación del litoral o a la propiamente marina para ambientar en su medio este monumento de clara vocación marítima. Todo es un canto a la biodiversidad de este rico ecosistema de Cantabria en el que nació y creció Antonio López, que hoy día se trata de preservar de las amenazas que se ciernen sobre él ${ }^{45}$.

El arquitecto catalán debió de conocer bien el medio natural de Comillas a través de sus estancias en la "Villa de los Arzobispos", particularmente en la que tuvo lugar en el verano de 1889, durante la cual se le menciona en la prensa como bañista. Su natural curiosidad le llevaría a hacer este acopio del universo biológico de aquel paraje que, además de sus baños de mar, ofrecía a los veraneantes el atractivo de su pintoresca naturaleza. En aquella estancia estival, además, debió de coincidir con Silvino Thos y Codina, ingeniero jefe del distrito minero de Barcelona y Gerona ${ }^{46}$. Éste fue autor, como hemos visto, del libro De Comillas à París (septiembre-octubre de 1889), formado a partir de los artículos que publicara en el Diario de Barcelona sobre sus impresiones de

\footnotetext{
${ }^{45}$ Con este objetivo se creó el Parque Natural de Oyambre mediante la Ley de Cantabria 4/1988, de 26 de octubre, y la posterior redacción del Plan de Ordenación de los Recursos Naturales (PORN). Para documentarnos sobre el ecosistema de la zona hemos utilizado el borrador de dicho Plan.

46 Nacido en Mataró en 1843 y fallecido en Barcelona en 1916, Silvino Thós y Codina fue, además de ingeniero, gran geólogo y humanista. Entre sus muchas publicaciones destaca la Descripción física, geológica y minera de la provincia de Barcelona, editada en Barcelona por la imprenta de León Tello en 1881. Se trata del primer mapa geológico de España, que surgió de una iniciativa de la Primera República española (Decreto de Gobierno de la República de 28 de marzo de 1873). En éste se disponía que los estudios y trabajos para la formación del Mapa Geológico de España a escala 1/400.000 se llevaran a cabo por todos los ingenieros del Cuerpo de Minas. También fue el traductor de la edición en castellano de la obra de Louis Siret Les premiers âges du metal dans le SudEst de l'Espagne. Anvers, 1887 (Las primeras edades del metal en el Sudeste de España, Barcelona, 1890). Silvino participó también del fervor catalanista de su época y fue amigo de Mossèn Verdaguer, a quien dedicó un ejemplar de la Descripción. Su hermano Terencio fue un famoso rondallayre y protector de los Jochs Florals. Cfr. Mascareñas y Hernández, Eugenio (1917): Sesión pública extraordinaria del día 16 de diciembre de 1916 en honor del académico difunto Silvino Thos y Codina: memoria necrológica / por el académico Eugenio Mascareñas y Hernández. Memorias de la Real Academia de Ciencias y Artes de Barcelona, Barcelona, 3ae época, v. 13, no 10 (1917) y Amorós Mestres, Josep (2001): "El primer mapa geológico de España", El Cuele, Boletín del Colegio Oficial de La Ingeniería Técnica Minera de Cataluña y Baleares, Núm. 33, Barcelona, marzo 2001.
} 
viaje $^{47}$. Es posible que con él, Domènech recorriera algunos de los parajes comillanos donde la naturaleza se muestra en todo su esplendor, y ambos compartieran juntos el descubrimiento de ese microcosmos vegetal y animal que dejó petrificado en el monumento como evocación permanente de los orígenes comillanos de Antonio López. La siguiente descripción de un "viaje submarino" de Comillas por parte del ilustre geólogo y humanista, pintoresca al tiempo que científica, muestra un espíritu muy cercano al plasmado por el arquitecto en la iconografía biomorfa de sus discos:

(...). Tan insensiblemente se pasa del mar á la tierra y de la tierra al mar que, aprovechando un momento de una marea baja, muy baja, me aventuro un dia a realizar una especie de viaje submarino, pero viaje á pié enjuto. Explicaré la paradoja. Las aguas del mar, al retirarse en su movimiento de reflujo, dejan al descubierto grandes lanchones de roca sobre los cuales me echo á andar como por unos muelles, salvando, sin embargo, como puedo, 1os hoyos y cortaduras y toda clase de desigualdades, que los muelles, cuidadosamente fabricados no presentan. Mientras voy andando, descubro en el fondo de las aguas grandes manchas de vejetacion submarina, que convierten dicho fondo en un eden o jardin; veo allí plantas de variedad de formas, tamaños y colores, verdes azules, tornasoladas, sobresaliendo sobre todas las algas por su gran talla; mis píes se apoyan sobre una verdadera colonia de mariscos pegados al suelo, patelas ó lapas fuertemente adheridas á la roca, como de costumbre; y de vez en cuando algunos cangrejos ó paguros, cubiertos con sus rojas corazas, pasan ensayando su conocido salto hácia atrás. En los hoyos que me rodean, convertidos en otros tantos aquariums distingo algunos pequeños gasterópodos ó caracoles, con su opérculo levantado, como la visera de un capacete, trepando perezosamente por las plantas marinas, á la manera de abejas que liban los cálices de las flores; en otros, desprovistos de vejetacion, los erizos ó castañas de mar hicieron de ellos presa y, taladrando en mil puntos su fondo, á la medida de sus cuerpos, lo han convertido en una especie de harnero. ¿Y qué bultos son esos que, como informes masas gelatinosas, avanzan por entre los canales que dividen mi improvisado sustentáculo? Pero aquí viene el pescador de pulpos y vamos á presenciar su trabajo. (... $)^{48}$.

${ }^{47}$ El viaje le llevó de Comillas a la capital francesa para asistir a la reunión de ingenieros que allí tuvo lugar con ocasión de la Exposición Universal de Paris de 1889.

48 Thos y Codina, Silvino, "De Comillas á París I", Diario de Barcelona, 26 de octubre de 1889, p. 13130. 

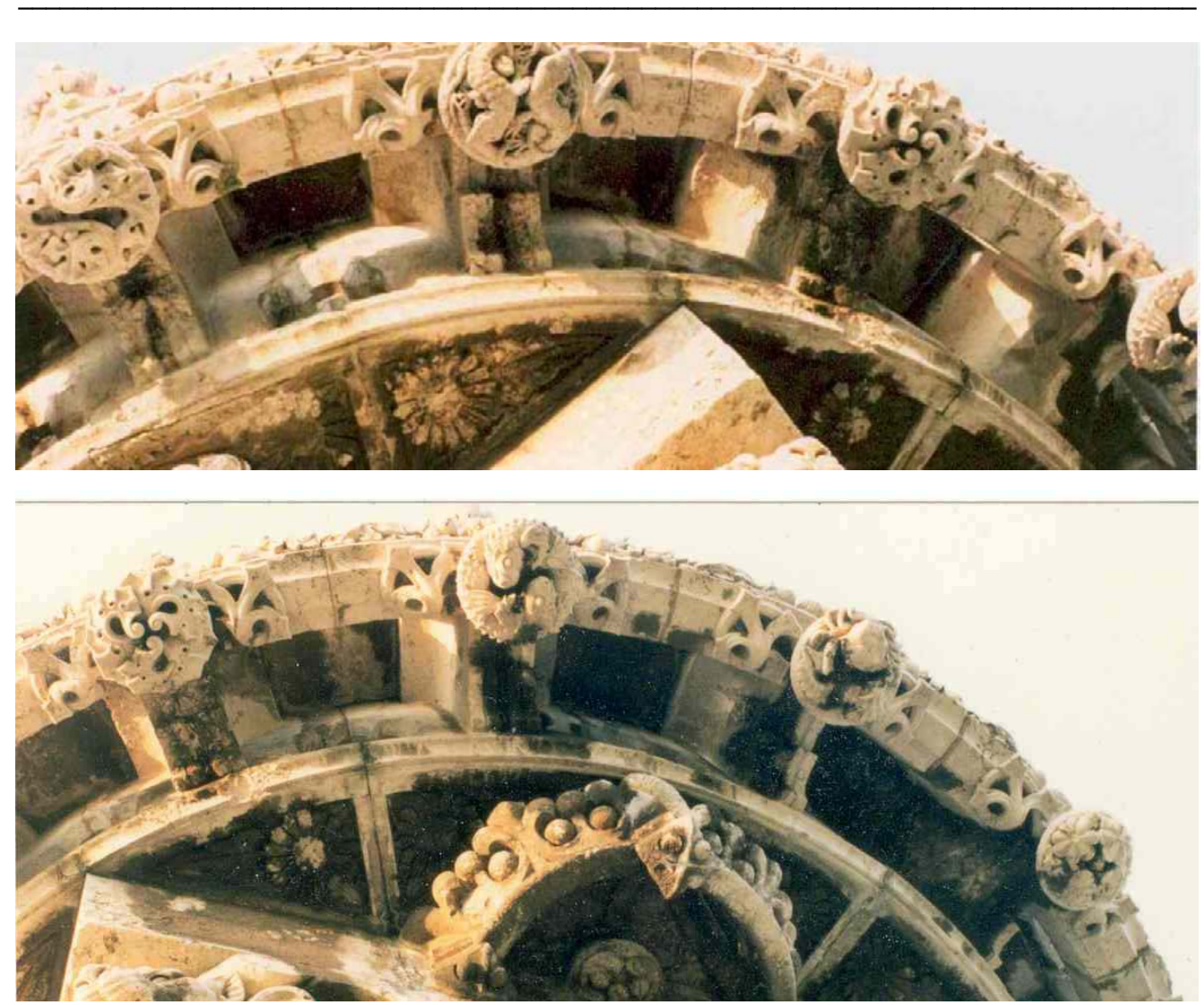

Figs. 9 y 10. Detalles de los discos decorativos del dosel del Monumento a Antonio López.

Quizás también evocación del paisaje de Comillas sea el relieve que decora el faldón del dosel circular, trabajado con motivos de hojas de roble y bellotas. Este relieve sustituye en el monumento construido a la idea original, expresada en el proyecto, de colocar en el mismo lugar la dedicatoria de la ciudad de Santander. Puede que de este modo Domènech quisiera integrar en "La estatua" las frondosas arboledas de castaños y robles que pueblan el sitio de Sobrellano ${ }^{49}$.

\footnotetext{
${ }^{49}$ En COAC, Demarcació Barcelona, Fondo Domènech i Montaner, carpeta C 1663/21 Monumento a Antonio López, carpeta C 1663/21 Monumento a Antonio López, se conserva una fotografía con el yeso que sirvió de modelo a estos relieves. Junto a él, se ve el modelo del capitel a medio tallar y los remates en forma de flor de lis del dosel. También aparece una moldura tallada con cascabeles, que se supone pertenece al Seminario, y el de las flores de corola radiante que decoran los intersticios internos del dosel. Ésta última parece más decorativa que simbólica y se parece a otros motivos que Domènech emplea en otras obras, pero podría tratarse también de una flor de la clase Magnoliopsida.
} 
La conclusión, por lo tanto, es que en el monumento que erigieron los comillanos a la memoria de su paisano predomina un tono bastante más íntimo que en la mayoría de la escultura conmemorativa de la época. No predomina aquí la idea de representar al gran patricio como modelo de emprendedor y ejemplo de virtud. Ese es el concepto que subyace en el memorial de Barcelona, donde los relieves del pedestal glosan los negocios de Antonio López como símbolo de progreso. En Comillas el discurso es distinto. El acento se ha puesto en la epopeya personal del homenajeado, resaltando sus raíces en la tierruca, y su vinculación al mundo del mar.

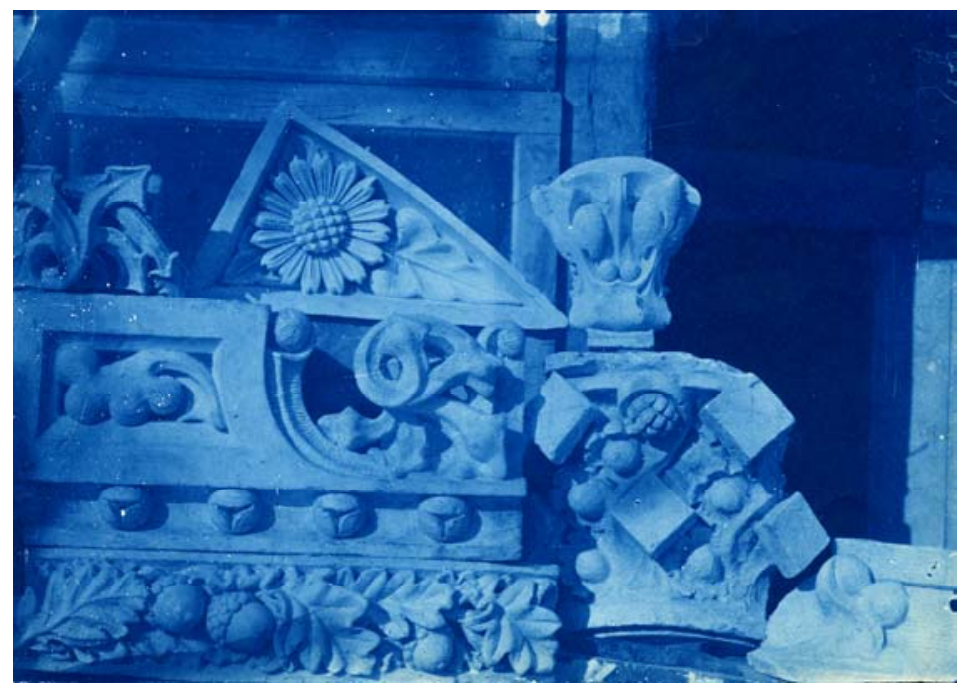

Fig. 11. Modelos de yeso para diversos detalles escultóricos del Monumento. AHCOAC (autor desconocido).

Quizás como en ningún otro ejemplo de la estatuaria monumental decimonónica ${ }^{50}$ se advierte en el proyecto de Domènech i Montaner el principio de la relación con el lugar, de la integración telúrica con el escenario natural que veremos después magistralmente expresada en el cementerio parroquial. Sin duda, contribuyó decisivamente a ello el alejamiento del núcleo urbano.

El monumento de Comillas trae irremediablemente al recuerdo el de Colón en Barcelona. Como en aquél, la estatua se eleva sobre una columna y mira al mar. La escala, lógicamente, es muy distinta, pero la adopción de la tipología columnaria se justifica en ambos casos por la necesidad de elevar lo más po-

\footnotetext{
${ }^{50}$ Así se puede deducir de la comparación con los ejemplos que trata Carlos Reyero en La escultura conmemorativa en España. La edad de oro del monumento público. 1820-1914, Madrid, Cátedra, 1999.
} 
sible una estatua concebida como faro para navegantes. Sin embargo, si en Barcelona el pedestal se plantea como el espléndido aislamiento de la figura del gran almirante, en Comillas se abraza a la tierra a través del zócalo, en un movimiento incipientemente orgánico que parece presagiar la cartilaginosa petrificación del monumento al Doctor Robert (Josep Llimona, 1904). La escalera también es un precedente de otro de los hitos de la escultura conmemorativa como es el monumento a Emilio Castelar de Madrid (Benlliure, 1908), pero si en éste es teatral escenificación de la alegoría, en el de Antonio López es invitación real a ascender e involucrarse físicamente en el homenaje.
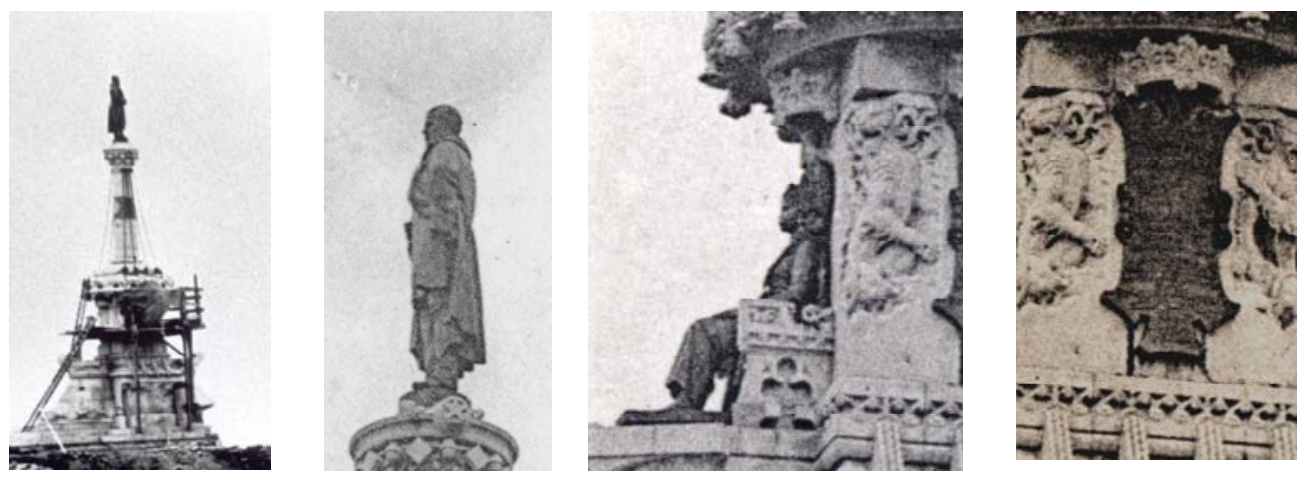

Figs. 12-15. Detalle del Monumento en la fotografía de Romualdo Moro, y tres detalles del mismo en la postal de 1910.

\section{El monumento tras la Guerra Civil.}

Durante la contienda de 1936-1939, el memorial del marqués de Comillas perdió todas las aplicaciones escultóricas de bronce ${ }^{51}$, incluida la estatua del homenajeado. Al parecer, la razón de tal expolio fue la de fundir el metal y emplearlo en la fabricación de cañones, de los que estaba tan escaso el Gobierno de la Segunda República. Unos documentos del AGA certifican que en septiembre de 1937 ya habían desaparecido los metales ${ }^{52}$.

\footnotetext{
${ }^{51}$ Sin embargo, y tal y como se puede apreciar en algunas postales antiguas en las que todavía se ven los bronces, las jarcias debieron de desaparecer con anterioridad.

52 En el Archivo General de la Administración, en la sección “Comillas. Agosto y septiembre 1937. destrozos en la ciudad", caja 103, sobre 7, se conserva una fotografía del monumento sin la estatua del marqués ni las demás piezas de bronce. Va acompañada de un pie de foto que dice: El monumento del Marqués de Comillas, cuya figura destruyeron los rojos. Comillas, 2-9-37. Lleva la signatura 30D/780 y el sello del Ministerio del Interior, Sección Técnica.
} 
Una vez finalizada la guerra fratricida, el conde de Ruiseñada inició las gestiones para reconstruir o reponer las partes faltantes ${ }^{53}$. En los archivos de Sant Cugat del Vallés ${ }^{54}$ y del Museu Frederic Marés hay bastante documentación al respecto que nos permite reconstruir el proceso de restauración.

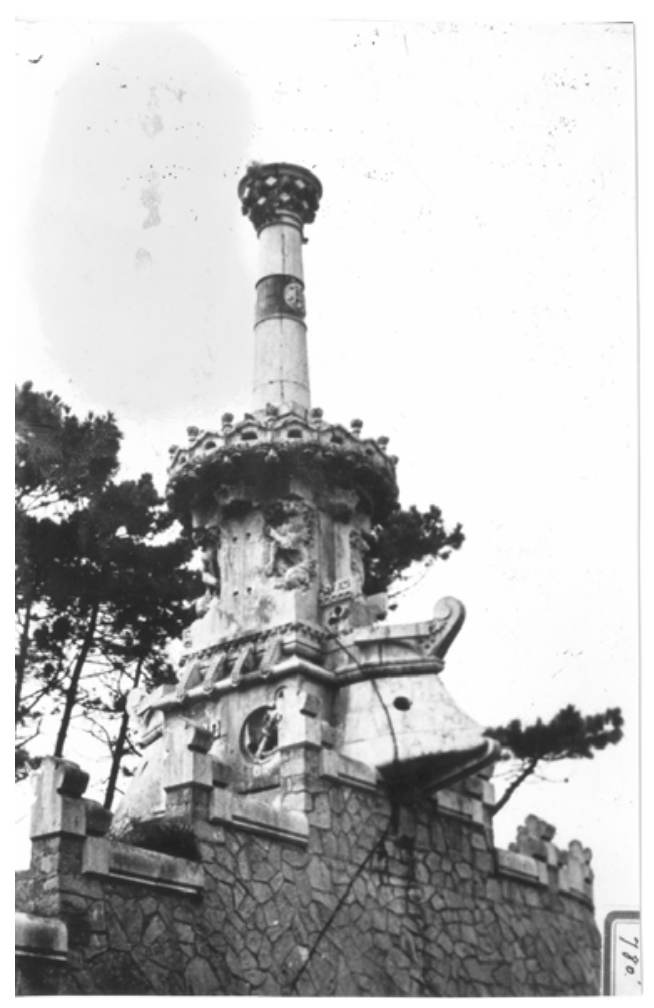

Fig. 16. El Monumento tras la Guerra Civil, sin la estatua.

\footnotetext{
${ }^{53}$ Juan Claudio Güell y Churruca (1907-1958), segundo conde de San Pedro de Ruiseñada, era hijo de Juan Antonio Güell y López Bacigalupi y Bru, tercer marqués de Comillas, y de Virginia Churruca y Dotres Brunet y Zinza. Contrajo matrimonio en Bilbao el 25.09.1928 con María del Carmen Martos y Zabalburu, 12 ${ }^{a}$ marquesa de Fuentes. Sus hijos fueron Alfonso Güell y Martos, cuarto marqués de Comillas, María de los Reyes Merry del Val y Melgarejo, Juan Güell y Martos, tercer. conde de Güell, y Pilar Güell y Martos, condesa de Mantagut Alto.

${ }^{54}$ Archivo Nacional de Cataluña, fondo Comillas. En el Doc. 040717 se guardan las cartas entre Ruiseñada y el Ayuntamiento de Comillas. En el Doc. 040754 la correspondencia entre el conde y Federico Marés. En el Museo Marés de Barcelona se conserva también un número de cartas considerable cruzadas entre Juan Claudio Güell y Churruca y el escultor. Éstas se refieren no sólo al monumento, sino también al nuevo sepulcro para Claudio López Bru en el Seminario (obra de Marés) y dos medallas conmemorativas.
} 
La primera carta, cronológicamente hablando, que conocemos está fechada el 13 de mayo de $1939^{55}$ y por ella Ruiseñada comunica al alcalde de Comillas, Pablo Azcárate, su intención de reponer la escultura de bronce del marqués, y propone como escultor a Federico Marés. En otra carta fechada al día siguiente, el conde se dirige a Marés y le dice que respecto al asunto de Comillas, como ya le ofrecí me he dirigido a la Comisión que ha de allegar recursos para la reposición de la estatua de mi bisabuelo y dadas las instrucciones que les he dado espero no adopten ningun acuerdo sin antes consultarme $e^{56}$.

De la correspondencia se deduce, pues, que en un principio hubo la intención de reproducir en bronce las esculturas perdidas. De acuerdo con ello, el 14 de junio del mismo año, el alcalde de Comillas comunica a Juan Claudio Güell y Churruca el hallazgo en Santander de la cabeza de la estatua de Antonio López ${ }^{57}$. Las siguientes $\operatorname{cartas}^{58}$ demuestran que se envían a Marés la cabeza modelada por Agapit Vallmitjana y unas postales para que el escultor se pueda hacer una idea de las proporciones, y elabore un presupuesto ${ }^{59}$. Éste se envía a Ruiseñada mediante una carta fechada el 12 de agosto de 1939 en donde se consignan los gastos por el modelaje, fundición a la cera perdida, cincelado, patinado de una estatua de gran tamaño representando al Sr. Marqués de Comillas. En el desglose se precisa que el presupuesto incluye no sólo la fundición de la estatua principal, sino también la de "Las Indias" y los escudos. El importe total es de 99.500 pesetas $^{60}$.

\footnotetext{
${ }^{55}$ Arxiu Nacional de Catalunya (ANC), fondo Comillas, Doc. 040717. Hay, no obstante, en el Doc. 040754 una carta anterior de Federico Marés al conde (12/04/1939) en la que, al tiempo que el escultor se refiere e unas reformas de adecentamiento en "el palacio" (se supone que el de Portaferrisa), hace una alusión al "monumento de Comillas".

${ }^{56}$ Museu Frederic Marés. Carta del conde de Ruiseñada a Federico Marés, Barcelona 14 de mayo de 1939.

${ }^{57}$ ANC, fondo Comillas, Doc. 040717.

${ }^{58}$ Ibíd:: Carta del 28 de junio de 1939 de Ruiseñada al alcalde de Comillas solicitando el envío de la cabeza y de las postales. Carta del 17 de julio de 1939 del alcalde de Comillas a Ruiseñada por la que se comunica el envío de la cabeza.

${ }^{59}$ En septiembre del año 1997 hicimos una indagación con los responsables del Museu Frederic Marés por si la cabeza original de la estatua se hubiera conservado en el museo, pero el resultado fue negativo.

${ }^{60}$ ANC, fondo Comillas, Doc. 040754. Carta de Marés a Ruiseñada del 12 de agosto de 1939. El desglose es el siguiente: Estatua: 24.500 pts. Símbolo América: 25.000 pts. Símbolo Oceanía: 25.000 pts. Escudos: 14.500 pts. Restauración en piedra: 6.000 pts. Embalajes, acarreos, etc.: 4.500 pts.
} 
Entre esta carta y la siguiente de que tenemos noticia hay un salto de dos años. Durante este lapso de tiempo se debió decidir acometer sólo la reposición de la imagen de Antonio López y no en bronce, sino en piedra. Obviamente, la causa de este recorte del proyecto fue de naturaleza económica y, en concreto, la lentitud con que la Comisión del Ayuntamiento de Comillas allegaba los fondos necesarios para la empresa ${ }^{61}$. La correspondencia siguiente, conservada en su totalidad en el Museu Frederic Marés, nos informa de que la estatua estaba terminada el 21 de abril de $1942^{62}$ y de que el precio total del trabajo cobrado por el escultor fue de $73.285,00$ pesetas, a los que hay añadir otras 4.714 pesetas en concepto de embalaje y una cantidad indeterminada por los gastos de transporte (por tren hasta Torrelavega o Cabezón de la Sal y desde aquí por carretera hasta Comillas) y andamiaje ${ }^{63}$. La escultura de Marés llegó a Comillas el 23 de junio de aquel año y enseguida se procedió al montaje de los andamios para preparar su colocación.

La inauguración de la estatua se produjo, finalmente, el 23 de julio de 1942, en el marco de las fiestas del cincuentenario del Seminario de Comillas y con la presencia del Nuncio, monseñor Cicognani. El acto fue bastante divulgado por la prensa del régimen a través de extensas crónicas ${ }^{64}$. A continuación recogemos la que publicó La Vanguardia:

A las once de la mañana se ha celebrado, en el panteón de los marqueses de Comillas, una misa de «réquiem», que ofició el obispo de Segovia, doctor don Luciano Pérez Platero. Estuvieron presentes el nuncio de Su Santidad, monseñor Cicognani; los obispos de Calahorra, Vitoria y auxiliar de Toledo; una re-

\footnotetext{
${ }^{61}$ Museu Frederic Marés. Carta del conde de Ruiseñada a Federico Marés, Madrid 27 de julio de 1941. Juan Claudio le comunica que, a dicha fecha, el Ayuntamiento había recaudado 22.000 pts., de las cuales le hace un anticipo de la mitad.

${ }^{62}$ Museu Frederic Marés. Carta del conde de Ruiseñada a Federico Marés, Madrid 25 de abril de 1942.

${ }^{63}$ Museu Frederic Marés. Carta del conde de Ruiseñada a Federico Marés, Barcelona 19 de mayo de 1942. De otras cartas posteriores dirigidas por el conde al escultor (San Sebastián, 14 de agosto y 16 de septiembre de 1942) se deduce que el Ayuntamiento abonó 22.339 pesetas más los dispendios del traslado y colocación de andamios, mientras que Juan Claudio Güell se hizo cargo del resto, es decir, unas 50.500 (incluyendo una rebaja que le hizo Marés del 10\% sobre la factura de 4.714 pts por el embalaje de la estatua y desplazamiento a Comillas).

${ }^{64}$ Véase por ejemplo en el diario $A B C$ del 24 de julio de 1942 el artículo titulado "Bodas de Oro de la Universidad de Comillas", p. 11.
} 
presentación de la Compañía Transatlántica, presidida por don Eduardo Fano, e1 comandante de Marina de Santander; familia de los marqueses de Comillas, alcalde y jefe local del pueblo y numerosos sacerdotes.

Terminado el acto, los asistentes se trasladaron al lugar donde se alza, la estatua del primer marqués de Comillas don Antonio López Piélago y López de la Madrid destruida por la horda, y que ha sido reconstruida ahora por el Ayuntamiento y la localidad de Comillas.

Al llegar al lugar donde se halla emplazado el monumento, se unió a la comitiva el gobernador civil y Jefe provincial del Movimiento de Barcelona.

El padre Sarabia, desde el pedestal, pronunció breves palabras para manifestar que el Seminario se adhiere al homenaje que el Ayuntamiento y la familia de los marqueses tributan al fundador de la Casa de Comillas.

Después, el padre Augurio Salgado leyó una poesía. Seguidamente, el párroco de Comillas, saludó, en nombre del pueblo al nuncio de Su Santidad.

Finalmente, habló el conde de Riuseñada (sic) de la familia del marqués de Comillas, quien expresó su gratitud al nuncio de Su Santidad y a las altas jerarquías y autoridades por su asistencia a1 acto, así como al pueblo de Comillas, que con su presencia en el homenaje demostraba su afecto; e hizo resaltar que el ilustre fundador de la familia Comillas ejerció sus actividades de carácter financiero, más que con carácter especulativo con el fin de elevar el bienestar a miles de hogares, ayudando así al engrandecimiento de nuestra Patria ${ }^{65}$.

La escultura de Marés reproduce en sus rasgos generales el modelo de Vallmitjana tal y como se podía ver en las postales de la época. Sin embargo, adolece de cierta rigidez y tosquedad. En descargo del escultor catalán se puede argumentar, que, al parecer, hubo problemas con la piedra por la época en que se iba a comenzar su esculpido. Como consecuencia de ello, en vez de emplearse material de las canteras de Montjuich, que se consideraba el más apropiado, se utilizó piedra de Gerona de grano más grueso ${ }^{66}$.

\footnotetext{
65 "Los actos jubilares de la Universidad Pontificia de Comillas. Homenaje a la memoria del Marqués de Comillas", La Vanguardia, 24 de julio de 1942, p. 5.

${ }^{66}$ Museu Frederic Marés. Carta de Ruiseñada a Federico Marés, Madrid 8 de noviembre de 1941. El conde muestra su contrariedad por los problemas con la piedra de Montjuich que se había pensado emplear. Después, en otra del 5 de diciembre siguiente, otorga finalmente la autorización el escultor para emplear la de Gerona. La estatua debió de comenzarse a trabajar, por lo tanto, muy a finales del año en curso.
} 

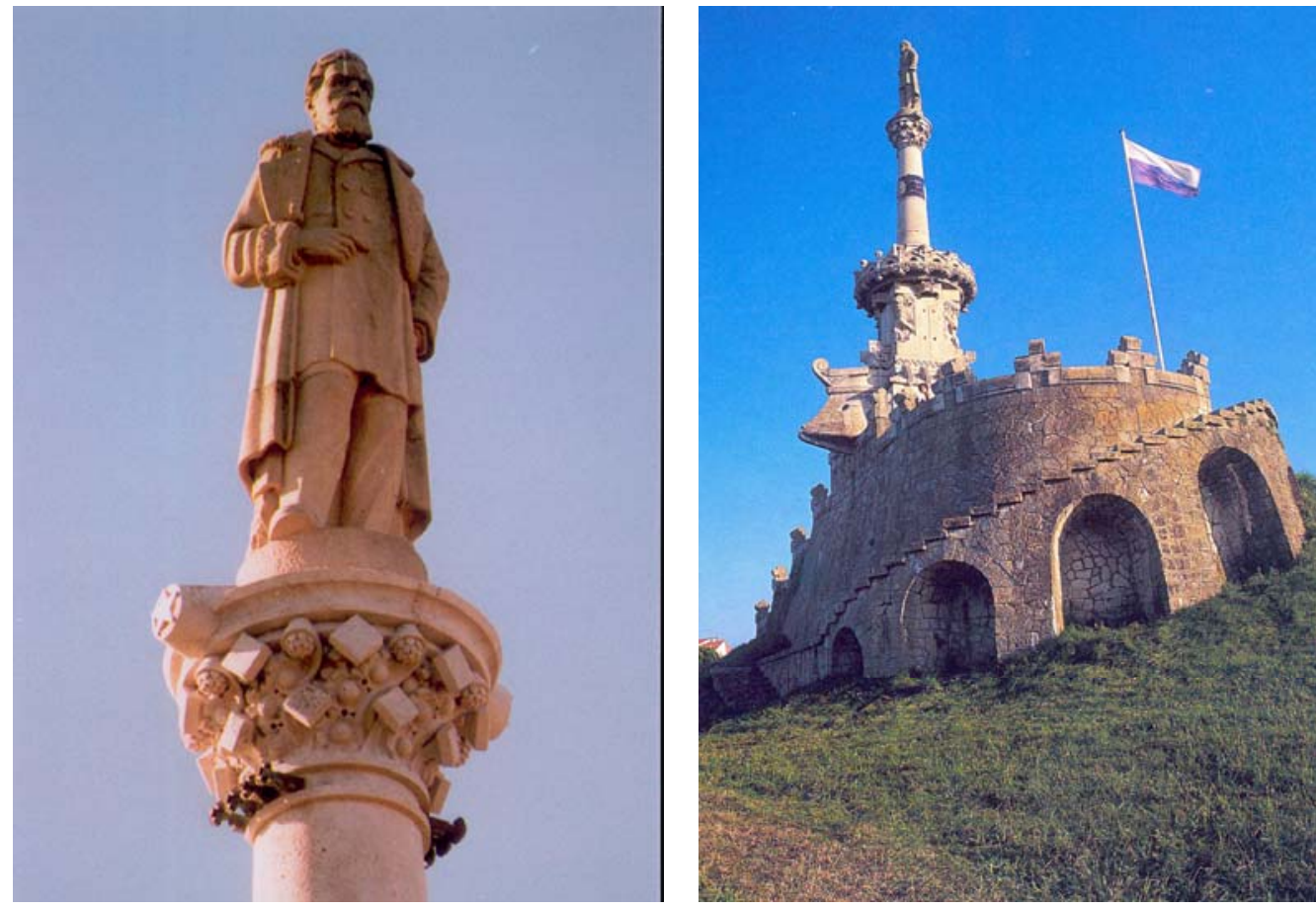

Figs. 17 y 18. El Monumento tras la intervención de Marés, tal y como se puede ver hoy en día.

\section{(Con la colaboración del Col·legi d'Arquitectes de Catalunya)}

\section{Bibliografía}

"L.D.M." [Lluís Domènech i Montaner] (1903): "Mélida (D. Arturo)", Anuario para 1903 de la Asociación de Arquitectos de Cataluña, 439-443, Barcelona.

AMORÓS MESTRES, Josep (2001): “El primer mapa geológico de España”, El Cuele, Boletín del Colegio Oficial de La Ingeniería Técnica Minera de Cataluña y Baleares, Núm. 33, Barcelona, marzo 2001.

Aramburu-Zabala, Miguel Ángel y Soldevilla Oria, Consuelo (2007): Arquitectura de los indianos en Cantabria (Siglos XVI-XX), Santander, ediciones de la librería Estudio.

BASSEGODA I NONELL, Juan (1971): “Arquitectos catalanes del siglo XIX: Cristòbal Cascante Colom", La Prensa, 26 de junio de 1971. 
CASCANTE DÁvila, Luis María (1999): Mi abuelo Cristóbal Cascante Colom, Barcelona [edición del autor].

Del RiO, José Antonio (1883): El Exmo. Sr. D. Antonio López y López, primer Marqués de Comillas, Santander, Imprenta de Río hermanos.

DOMÈNECH I MONTANER, Lluís y VILASECA, Josep (1875): “Lo monument á Clavé", La Renaixensa, Año V, núm. 10, 28 de febrero de1875, pp. 341-346

Domenechiana. Revista del centre d'estudis Lluís Domènech i Montaner, vol. 1, septiembre de 2013, Canet de Mar.

GuITART, Benito (1924): “Don Luis Doménech i Montaner", Arquitectura, año VI, núm 57, enero [1924] Madrid, p. 6

LACUESTA, Raquel (1976): Cristóbal Cascante, arquitecto. Trabajo de investigación inédito. Barcelona

LACUESTA, Raquel (2002): “Cristóbal Cascante i Colom (1851-1889)", Materials del Baix Llobregat, 8. [2002], pp. 93-98. [Parte de una serie de artículos bajo el título de "Síntesis biogràfiques de diferents arquitectes històrics amb activitat a la comarca del Baix Llobregat"].

L'arquitecte Lluís Domènech i Montaner, Exposición organizada por la Fundació La Caixa, Palma-Lleida, Fundació La Caixa, 1996.

Lluís Domènech i Montaner. Arquitecto modernista. [Catálogo de la exposición de abril-mayo de 1990 en Madrid, Sala Velázquez de Caja de Barcelona], Barcelona, Fundación Caja de Barcelona, [1990].

MASCARENAAS y HERNÁNDEZ, Eugenio (1917): Sesión pública extraordinaria del día 16 de diciembre de 1916 en honor del académico difunto Silvino Thos y Codina: memoria necrológica / por el académico Eugenio Mascareñas y Hernández. Memorias de la Real Academia de Ciencias y Artes de Barcelona, Barcelona, 3ª época, v. 13, no 10 (1917)

MOYA IDÍGORAS, Juan (1951): “En el centenario de D. Arturo Mélida y Alinari (1849-1902)", Academia, Madrid, 1951, pp. 3-8.

NAVASCUÉS, Pedro (1972): “Arturo Mélida y Alinari, 1849-1902”, Goya, núm. 106, Madrid, 1972, pp. 234-241.

CASAdo Rigalt, Daniel (2006): José Ramón Mélida (1856-1933) y la arqueología española, Volumen 13 de Publicaciones del Gabinete de Antigüedades de la Real Academia de la Historia, Antiquaria Hispánica; 13, Madrid. 
Perez Nieva, Alfonso (1893): “Comillas", El Globo, año XIX, tercera época, núm. 6.507, 3 de septiembre 1893, p. 1.

PÉrez Nieva, Alfonso (1893): “Revista de Madrid", La Dinastía, 18 de septiembre de 1893.

Puig I CADAFAlCH, Josep (1902): “Don Luís Doménech Montaner”, Hispania, núm. 93, 30 de diciembre de 1902, pp. 539-557.

RAHOLA, Federico (1889): “Una visita á los talleres Vidal”, La Vanguardia, 14 de julio de 1889, pp. 4 y 5.

SÀIZ I XIQUÉS, Carles (2013): Domènech i Montaner. Articles publicats (20092012), Canet de Mar, Edicions Els 2 pins.

SAMA, Antonio (2011): Gaudí y la arquitectura de la Renaixença en Comillas, (tesis doctoral inédita), Madrid, Universidad Complutense.

SAMA, Antonio (2012): “El sueño de unas Jornadas de verano: arte y metamorfosis en la celebración de los veraneos regios de Comillas (1881 y 1882)", en Actas de las I Jornadas Internacionales de Investigación Arte y Ciudad, Madrid, Facultad de Ciencias de la Información, Universidad Complutense, (24-25 de noviembre de 2011), 2012, pp. 75-91. http://www.arteyciudad.com /revista/index.php/actas/article/view/34

SAZATORNIL RUIZ, Luis (1996): Arquitectura y desarrollo urbano de Cantabria en el siglo XIX, Universidad de Cantabria, Colegio Oficial de Arquitectos de Cantabria, Fundación Marcelino Botín, Santander.

Thos y CodinA, Silvino (1890): De Comillas a París (agosto a octubre de 1889), $2^{a}$ ed., Barcelona: A. López Robert imp.

Vidal y C. Talleres y almacenes Diputación 436, Barcelona. Cerrajería y bronces suntuarios. Mobiliario y decorado interior de habitaciones y edificios públicos. Cristales grabados y esmaltados para vidrieras y espejos. [Álbum comercial de la casa "Vidal y Cia."], [Barcelona], s.d. [1888 o posterior]. 